\title{
The RNA helicase DHX36/G4R1 modulates C9orf72 GGGGCC repeat- associated translation
}

\author{
Yi-Ju Tseng ${ }^{1,2}$, Siara N. Sandwith ${ }^{3}$, Katelyn M. Green ${ }^{1}$, Antonio E. Chambers ${ }^{3}$, Amy Krans ${ }^{1}$, \\ Heather M. Raimer ${ }^{4}$, Meredith E. Sharlow ${ }^{3}$, Michael A. Reisinger ${ }^{3}$, Adam E. Richardson ${ }^{3}$, Eric D. \\ Routh $^{5}$, Melissa A. Smaldino ${ }^{3}$, Yuh-Hwa Wang ${ }^{4}$, James P. Vaughn ${ }^{6}$, Peter K. Todd ${ }^{\# 1,7}$, Philip J. \\ Smaldino $\#, 3$
}

1 University of Michigan, Department of Neurology, Ann Arbor, MI

2 Cellular and Molecular Biology Graduate Program, University of Michigan, Ann Arbor, MI 48109, USA

3 Ball State University, Department of Biology, Muncie, IN

4 University of Virginia, Department of Biochemistry and Molecular Genetics, Charlottesville, VA

5 Lineberger Comprehensive Cancer Center, University of North Carolina at Chapel Hill, Chapel Hill, NC 6 Nanomedica, Inc., Winston-Salem, NC

7 Ann Arbor VA Medical Center, Ann Arbor, MI

\# co-corresponding authors 


\section{ABSTRACT:}

GGGGCC $\left(\mathrm{G}_{4} \mathrm{C}_{2}\right)$ hexanucleotide repeat expansions (HRE) in C9orf72 are the most common genetic cause of amyotrophic lateral sclerosis (ALS) and frontotemporal dementia (FTD). Repeat-associated non-AUG (RAN) translation of this expansion generates toxic proteins that accumulate in patient brains and contribute to disease pathogenesis. The DEAH-Box Helicase 36 (DHX36/G4R1) plays active roles in RNA and DNA G-quadruplex (G4) resolution in cells. As $\mathrm{G}_{4} \mathrm{C}_{2}$ repeats form $\mathrm{G} 4$ structures in vitro, we sought to determine the impact of manipulating $\mathrm{DHX36}$ expression on repeat transcription and RAN translation. We found that DHX36 depletion suppresses RAN translation from reporter constructs in a repeat length dependent manner while overexpression of $\mathrm{DHX} 36$ enhances $\mathrm{RAN}$ translation from $\mathrm{G}_{4} \mathrm{C}_{2}$ reporter RNAs. Taken together, these results suggest that $\mathrm{DHX} 36$ is active in regulating $\mathrm{G}_{4} \mathrm{C}_{2}$ repeat translation, providing potential implications for therapeutic development in nucleotide repeats expansion disorders. 


\section{INTRODUCTION:}

$\mathrm{A} \mathrm{G}_{4} \mathrm{C}_{2}$ hexanucleotide repeat expansion (HRE) within the first intron of C9orf72 is a major genetic cause of amyotrophic lateral sclerosis and frontal temporal dementia (C9 FTD/ALS) $)^{1,2}$. Typically, humans have $\sim 2-28$ repeats, while disease associated alleles have $>30$ and often hundreds to thousands repeats ${ }^{3,4}$. C9 FTD/ALS represents over $40 \%$ of the familial cases and upwards of $10 \%$ of the sporadic cases of ALS in European populations ${ }^{5}$. Despite intense research efforts since its discovery in 2011, C9 FTD/ALS remains a progressive and fatal condition without effective treatment ${ }^{1,2,6}$.

Both DNA and RNA $\mathrm{G}_{4} \mathrm{C}_{2} \mathrm{HRE}$ sequences are prone to folding into G-quadruplex (G4) structures in vitro ${ }^{6-13}$. G4 structures are dynamic, nucleic acid secondary structures consisting of an assembly of vertically stacked guanine-tetrad building blocks. G4 structures are stabilized by Hoogsteen hydrogen bonding and monovalent cations, especially $\mathrm{K}^{+14-16}$. G4 structures have been directly observed in human cells ${ }^{17-19}$, with $>700,000$ G4 motifs residing throughout the human genome ${ }^{20,21}$. G4 structures motifs are non-randomly distributed, with enrichment in gene promoters, untranslated regions, and origins of replication, suggesting functional roles in transcription, translation, and replication, respectively ${ }^{20-24}$. Taken together, G4 structures are linked to each of the major toxicities observed in C9 FTD/ALS patient neurons.

The underlying pathogenesis of the $\mathrm{G}_{4} \mathrm{C}_{2} \mathrm{HRE}$ involves at least three inter-related pathways, each of which is foundationally linked to aberrant $\mathrm{G} 4$ structures. The $\mathrm{G}_{4} \mathrm{C}_{2}$ HRE as DNA impairs mRNA transcription and alters the epigenetics of the C9orf72 locus, decreasing C9orf72 protein expression ${ }^{25}$. Endogenous C9orf72 protein is important for endosomal trafficking and autophagy in neurons, and its loss is detrimental to neurons and impacts inflammatory pathways relevant to $A L S^{25}$. When transcribed, the resultant $\mathrm{G}_{4} \mathrm{C}_{2}$ mRNA species folds into $\mathrm{G} 4$ structures, which coalesce as RNA foci in complex with RNA binding proteins, impairing RNA processing ${ }^{2,6}$. If transcribed $\mathrm{G}_{4} \mathrm{C}_{2}$ HRE mRNAs reach the cytoplasm, they can serve as a template for repeat-associated non-AUG initiated (RAN) translation. RAN translation from $\mathrm{G}_{4} \mathrm{C}_{2}$ repeat RNA (C9RAN) produces dipeptide repeat proteins (DPRs) that aggregate in proteinaceous inclusions. 
C9RAN DPRs proteins cause proteotoxic stress and disrupt nucleocytoplasmic transport ${ }^{13,26,27}$.

The mechanisms underlying C9RAN remains enigmatic ${ }^{28}$. Initiation can occur at either an upstream near-AUG codon (CUG) or within the repeat itself ${ }^{29-32}$. RNA helicases such as elF4B, elF4H and DDX3X play active and selective roles in the translation process, as do the ribosomal accessory protein RPS25 ${ }^{33-36}$. RAN translation also demonstrates a selective enhancement in response to cellular stress pathways which activate stress granule formation and suppress global translation through phosphorylation of elF2 $\alpha^{29}$ $31,37,38$. Consistent with this, modulation of the alternative ternary complex protein elF2A or PKR expression can alter C9RAN translation. ${ }^{32,38}$

Given their potentially central role in $\mathrm{G}_{4} \mathrm{C}_{2}$ repeats in C9 FTD/ALS pathogenesis, we explored factors responsible for G4 resolution within cells. One such enzyme, DHX36 (aliases: G4R1 and RHAU), is a member of the DExH-box family of helicases ${ }^{39}$. DHX36 accounts for the majority of the tetramolecular G4 DNA and RNA helicase activity in HeLa cell lysates ${ }^{40,41}$. DHX36 binds to a diverse array of unimolecular DNA and RNA G4 structures with the tightest affinity of any known G4 structure binding protein and can catalytically unwind these structures in isolation ${ }^{6,42-52}$. DHX36 associates with thousands of G4-containing DNA and mRNA sequences, facilitating both their transcription and translation ${ }^{53-55}$. Moreover, DHX36 plays an active role in stress granule dynamics, where its loss can trigger spontaneous formation of stress granules and changes in their dissolution after a transient stress exposure ${ }^{53}$. Thus, DHX36 has the potential to influence $C 9$ orf72 transcription and $\mathrm{G}_{4} \mathrm{C}_{2}$-repeat RNA stability, localization, and RAN translation ${ }^{23,46}$.

Here we find that DHX36 knockdown and knockout selectively suppresses C9RAN translation as well as RAN translation at CGG repeats from reporters in human cells. In contrast, overexpression of WT DHX36, but not a mutant form of DHX36 which lacks helicase activity, enhances RAN translation. These effects are largely translational as we observe suppression of C9RAN translation in an in vitro DHX36 KO cell lysate translation system while observing no significant alterations in reporter RNA in response to knockdown or overexpression of DHX36. Loss of DHX36 also precludes stress- 
dependent upregulation of C9RAN translation consistent with its role in stress granule formation. Taken together, these results suggest modulation of G4 structures at the RNA level by candidate $G 4$ helicases such as $D H X 36$ impact $\mathrm{G}_{4} \mathrm{C}_{2}$ repeat expansion translation implicated in C9 FTD/ALS.

\section{RESULTS:}

\section{DHX36 directly binds C9-repeat G4 DNA in vitro}

To determine if DHX36 directly binds to C9 G4 DNA structures, we performed electrophoretic mobility shift assays (EMSAs) with a DNA oligonucleotide composed of five $\mathrm{G}_{4} \mathrm{C}_{2}$-repeats with a 3' unstructured tail shown to be require for $\mathrm{G} 4$ binding 49,56 (referred to hereafter as " $\left(\mathrm{G}_{4} \mathrm{C}_{2}\right)_{5}$-DNA"). $\left(\mathrm{G}_{4} \mathrm{C}_{2}\right)_{5}$-DNA was folded into $\mathrm{G} 4$ structures by heating and cooling in the presence of $\mathrm{KCl}$. As a negative control of non-G4 DNA, $\left(\mathrm{G}_{4} \mathrm{C}_{2}\right)_{5}$-DNA was heated and cooled in the absence of $\mathrm{KCl}$. $\mathrm{G} 4\left(\mathrm{G}_{4} \mathrm{C}_{2}\right)_{5}$-DNA and nonG4 $\left(\mathrm{G}_{4} \mathrm{C}_{2}\right)_{5}$-DNA was incubated with purified recombinant DHX36 (rDHX36) under noncatalytic conditions (-ATP, +EDTA) so that binding could be visualized on a gel (Figure 1A, C). As an additional control, this was repeated with scrambled C9-repeat DNA, where the C9-repeat sequence was rearranged as to prevent G4 structure formation. (Figure 1B-C). Following incubation, the samples were subjected to non-denaturing polyacrylamide gel electrophoresis (PAGE). In the absence of $\mathrm{KCl}$, a single band is observed for $\left(\mathrm{G}_{4} \mathrm{C}_{2}\right)_{5}$-DNA. When $\mathrm{KCl}$ is added, slower migrating bands are observed, consistent with the formation of $\mathrm{G} 4$ structures. Incubation of $\left(\mathrm{G}_{4} \mathrm{C}_{2}\right)_{5}$-DNA with rDHX36 resulted in a shift of the DNA to the upper region of the gel indicating direct binding. Notably, some unstructured $\left(\mathrm{G}_{4} \mathrm{C}_{2}\right)_{5}-\mathrm{DNA}$ is present in the $\mathrm{KCl}$-containing reactions and is not bound by DHX36, further suggesting selective binding to G4 structure. In the absence of $\mathrm{KCl}$ (i.e. non-G4 conditions), binding of $r D H X 36$ to $\left(\mathrm{G}_{4} \mathrm{C}_{2}\right)_{5}-\mathrm{DNA}$ is substantially reduced. Furthermore, scrambled $\left(\mathrm{G}_{4} \mathrm{C}_{2}\right)_{5}$-DNA does not form $\mathrm{KCl}-$ dependent higher-ordered structures and is not a strong binding substrate for rDHX36 even in the presence of $\mathrm{KCl}$. Taken together, these data suggest that DHX36 directly binds to C9 HRE DNA in a G4-dependent manner in vitro. 


\section{DHX36 enhances transcription of C9-repeat DNA in vitro}

G4 DNA structures impede the transcription of C9-repeat RNA and T7 elongation ${ }^{6}$. Given that DHX36 is a helicase that resolves G4 structures, we hypothesized that DHX36 might facilitate the transcription of C9-repeat RNA. To test this, we performed an in vitro transcription assay with a plasmid containing $70 \mathrm{G}_{4} \mathrm{C}_{2}$ repeats (pCR8$\left.\left(\mathrm{G}_{4} \mathrm{C}_{2}\right)_{70}\right)$ driven by a T7 RNA polymerase reporter ${ }^{27}$. We incubated the plasmid with T7 polymerase in the presence and absence of $\mathrm{rDHX} 36$. A T7 plasmid containing a nano luciferase (NLuc) gene was used as a non-G4 control. The resulting RNA transcripts were subjected to denaturing urea gel electrophoresis. We found that rDHX36 significantly increased the length of RNA transcripts yielded from $\mathrm{G}_{4} \mathrm{C}_{2}$ repeat $D N A$, but not from NLuc (Figure 1D-E). However, the total RNA generated from $\mathrm{G}_{4} \mathrm{C}_{2}$ repeat DNA and NLuc DNA was not significantly different between $r D H X 36$ and control reactions (Supplemental Figure 1). These data suggest that rDHX36 facilitates efficient and complete in vitro transcription of G4 C9-repeat sequences by T7 RNA polymerase, but may not impact its overall production.

\section{DHX36 depletion modifies C9RAN translation}

We next evaluated the impact of altering DHX36 expression on C9RAN translation. To accomplish this, we utilized previously described C9RAN translation-specific nanoluciferase reporters (C9-NLuc) ${ }^{29}$. These reporters include $70 \mathrm{G}_{4} \mathrm{C}_{2}$ repeats in the context of the first C9orf72 intron. This sequence is inserted 5 ' to a nanoluciferase (NLuc) whose start codon is mutated to GGG and with a 3x FLAG tag fused to its carboxyl terminus (Figure 2A). Single base pair insertions between the repeat and NLuc allow for evaluation of translation in all three reading frames. An AUG-initiated NLuc serves as a positive control for canonical translation. An AUG initiated firefly luciferase (AUG-FF) is included as a transfection control ${ }^{29}$.

To study the effects of loss of DHX36, we used a previously described stable and inducible knockdown (DHX36 KD) HeLa cell line ${ }^{41,57}$ (Figure 2B, Supplemental Figure 
2A-E). Treatment of these cells with doxycycline for $96 \mathrm{hrs}$ significantly reduced DHX36 expression as measured by immunoblot (Figure 2C). Comparing between control and DHX36 KD cells with transiently transfected C9-NLuc reporters, DHX36 KD selectively decreased C9RAN translation in the GA $(+0)$, GP $(+1)$ and $\mathrm{GR}(+2)$ reading frames, relative to AUG-NLuc when normalized to AUG-FF as transfection control (Figure 2D, Supplemental Figure 2F). C9RAN translation in the GA and GR reading frames was also selectively decreased in the DHX36 KD line with doxycycline induction when compared to the DMSO vehicle treated cells, suggesting that the effect was DHX36specific (Supplemental Figure 3A). Either no significant transcript bias or an opposite production bias favoring DHX36 KD was observed for AUG transcripts (Figure 2D and F). To confirm these findings using an orthogonal readout, we performed immunoblots to detect FLAG signal on lysates from both control and DHX36 KD cells. As we had observed in our luciferase assays, DHX36 KD led to a significant decrease in the GA C9RAN-NLuc protein without impairing AUG translation of NLuc from a separate reporter (Figure 2E).

To determine if loss of DHX36 might have broader effects on protein translation in these cells, we performed a SUnSET assay, which measures puromycin incorporation into nascent proteins ${ }^{58}$. Treatment with puromycin for 10 minutes led to a smear of proteins detectible by puromycin immunoblot. There was no difference between DHX36 Ctrl and $\mathrm{KD}$ cells in this assay (Supplemental Figure 2D-E), suggesting that rates of global translation is not demonstrably affected by knockdown of DHX36 in these cell lines.

\section{DHX36 depletion impairs RAN translation from CGG repeats}

RAN translation occurs at multiple different GC rich repeat sequences, some of which are capable of forming G4 structures and some of which are less likely to form such structures. We therefore evaluated whether DHX36 KD impacts RAN translation at these other repeats. Expansion of a transcribed CGG repeats in the 5'UTR of FMR1 causes Fragile X-associated Tremor/Ataxia Syndrome (FXTAS) ${ }^{59,60}$. RAN translation from this repeat in the +1 reading frame generates a polyglycine protein (FMRpolyG) that accumulates within inclusions in patient brains and model systems ${ }^{59,61-64}$. This 
repeat is capable of forming either a hairpin structure or a G4 structure in vitro ${ }^{65-68}$. Using a NLuc reporter with 100 repeats $\left(+1 \mathrm{CGG}_{100}\right)^{69}$, we observed that KD of DHX36 significantly suppressed CGG RAN translation of FMRpolyG on a scale comparable to that of C9RAN reporters (Figure 2F). This decrease in CGG RAN translation was also evident by immunoblot (Figure 2E).

We next measured reporter mRNA levels in transfected Ctrl and DHX36 KD cells. Surprisingly, we observed only a small decrease in mRNA production that was not statistically significant (Figure 2G). In parallel, we also evaluated the impact of DHX36 overexpression on reporter expression. As with KD, overexpression of DHX36 did not significantly impact steady state reporter RNA expression in HeLa Cells (Supplemental Figure 5). These data suggest that the suppression of RAN translation in DHX36 KD cells is most likely a post-transcriptional event.

\section{DHX36 KO impairs in-cell and in vitro C9RAN translation}

As a second assay system in which to study the effect of DHX36, we generated a DHX36 stable knockout (DHX36 KO) Jurkat cell line using a CRISPR/Cas9 targeting approach. Wildtype Jurkat cells (WT) had no mutations at the DHX36 locus (INDEL: 0/0) while DHX36 KO Jurkat cells (DHX36 KO) had single allele KO disruption on one allele and a 6bp insertion on the other allele at the target site (INDEL: $+5 /+6$ )

(Supplemental Figure 4A-B). Western blot analysis showed elimination of full length DHX36 protein in Jurkat DHX36 KO cell lines (Figure 3A). Jurkat DHX36 KO cells exhibited impaired RAN translation across all three potential $\mathrm{G}_{4} \mathrm{C}_{2}$ reading frames, similar to what we observed in HeLa DHX36 KD cells (Figure 3B).

The effects of DHX36KD on RAN translation product generation could theoretically be elicited by changes in RNA or protein stability or by actively impacting protein translation. To investigate this question, we utilized an in vitro translation assay using lysates derived from DHX36 WT or KO Jurkat cells. Previous studies in similar conditions demonstrated that we could accurately measure C9RAN translation in this context and that production from our RAN reporters is not dependent on mRNA or 
reporter stability ${ }^{29,69}$. We harvested Jurkat DHX36 WT and KO cell lysates, added AUG or $\mathrm{G}_{4} \mathrm{C}_{2}$ repeat $\mathrm{RNA}$ in $\mathrm{GA}(+0)$ frame and in vitro translated for 2 hrs (Figure $4 \mathbf{C}$, Supplemental Figure 4C). AUG-NLuc translation from DHX36 KO lysates was consistently lower than that from WT Jurkat lysates. However, this effect was much larger for GA-NLuc reporters, which exhibited 36\% as efficient a translation in DHX36 KO lysates compared to WT lysates over $>4$ independent experiments (Supplemental Figure 4C). Together, these results suggest that loss of DHX36 suppresses RAN translation from $\mathrm{G}_{4} \mathrm{C}_{2}$-repeats in multiple reading frames of $\mathrm{G}_{4} \mathrm{C}_{2}$-repeats and is mainly acting at the level of translation.

\section{The effect of DHX36 on C9RAN translation is dependent on repeat length}

Translation of C9RAN reporters in the GA reading frame initiates primarily from an upstream CUG start codon that supports translation even at small repeat sizes $29,31,32,70$. If DHX36 contributes to RAN translation by resolving G4 structures, then we would predict that the loss of DHX36 would selectively reduce translation for transcripts with larger repeats. In HeLa cells, expression of C9 GA frame reporters with 3x, 35x, and $70 x \mathrm{G}_{4} \mathrm{C}_{2}$ repeats was selectively suppressed by DHX36 loss at the larger repeat sizes (Figure 4A-B, Supplemental Figure 3B). Similar results were observed in Jurkat DHX36 stable KO cells (Figure 4C). These results suggest that loss of DHX36 selectively acts to reduce C9RAN translation in a repeat length dependent manner.

\section{The effect of DHX36 overexpression on C9RAN DPRs expression}

Since depletion of DHX36 results in a significant decrease in C9RAN translation, we wondered if overexpression of DHX36 enhances C9RAN. To address this, we expressed either a DHX36 WT or a DHX36-E335A mutant which lacks the helicase activity required to unwind G4 structures in parental HeLa cells. To ascertain the impact of DHX36 on translation in particular, we conducted studies using transfected in vitro transcribed C9RAN reporter mRNAs. In HeLa cells, overexpression of DHX36 significantly increased C9RAN from transfected reporter RNAs in all three sense 
reading frames. This effect was specific to DHX36 WT, as DHX36-E335A has no effect on C9RAN DPRs production when normalized to the FFLuc mRNA reporters and western blot analysis confirmed this relationship (Figure 5). These data suggest that DHX36 acts post-transcriptionally to enhance RAN translation.

\section{Knockdown of DHX36 prevents stress dependent upregulation of RAN translation}

Activation of the integrated stress response (ISR), which triggers phosphorylation of elF2 $\alpha$ and formation of stress granules (SGs), suppresses global protein translation initiation by impairing ternary complex recycling ${ }^{71-75}$. Paradoxically, ISR activation enhances RAN translation from both $\mathrm{CGG}$ and $\mathrm{G}_{4} \mathrm{C}_{2}$ repeats, and repeat expression in isolation can trigger SG formation $29,30,32,37$. Loss of DHX36 induces spontaneous stress granule formation, suggesting that DHX36 may play a role in G4 structure-induced cellular stress ${ }^{53}$. We therefore wondered what impact loss of DHX36 would have on regulation of RAN translation in the setting of ISR activation. We co-transfected C9NLuc and FFLuc into DHX36 control or DHX36 KD HeLa cells and then treated them with $2 \mu \mathrm{m}$ of the ER stress inducer Thapsigargin ( $\mathrm{Tg}$ ) for $5 \mathrm{hrs}$. Tg treatment decreased expression of FFLuc in both Ctrl cells and in DHX36 KD cells, which is consistent with appropriate activation of the ISR in these cells (Figure 6A, right). Consistent with prior studies $^{29,37}$, Tg treatment in DHX36 control cells elevated C9RAN reporter levels compared to DMSO treatment. However, depletion of DHX36 precluded this upregulation in C9RAN by Tg (Figure 6A). Similar findings were also observed by immunoblot in studies where we co-transfected the C9RAN reporters and GFP as a control for transfection and AUG initiated translation (Figure 6B). These data suggest that $\mathrm{DHX} 36$ may play a role in regulating the stress induction of RAN translation induced by the ISR.

\section{DISCUSSION:}

DNA and RNA G-quadruplex (G4) structures strongly influence both gene transcription and mRNA stability, localization and translation. Moreover, G4 structures are implicated in a number of human disorders, including C9 FTD/ALS ${ }^{76,77}$. Here we find that a major 
human G4 helicase, DHX36, enhances C9RAN translation from expanded $\mathrm{G}_{4} \mathrm{C}_{2}$ repeat reporter RNAs in human cells. These effects on RAN translation require DHX36 helicase activity on G4 RNA. DHX36 is also required for efficient C9RAN and CGG RAN translation as knockdown or knockout of DHX36 in human cells suppressed RAN translation from both $\mathrm{G}_{4} \mathrm{C}_{2}$ and $\mathrm{CGG}$ repeats. We also observe a robust suppression of in vitro C9RAN translation in DHX36 KO cell derived lysates. Overall, these data are consistent with a model whereby DHX36 binds to and unwinds GC rich repeat RNA structures and enhances their non-AUG initiated translation with a potential secondary role in enhancing repeat transcription (Figure 7).

The observed effects on C9RAN reporter generation are largely post-transcriptional. While we do observe a stimulatory effect of DHX36 on T7 polymerase transcription from a C9-repeat in vitro (Figure 1D-E), we do not observe changes in C9-repeat RNA levels in cells following DHX36 KD or overexpression (Figure 2G, Supplemental Figure 5). We also show that DHX36 directly binds to C9-repeat DNA with a binding affinity of $\sim 10$ 100 less than previously reported for pure G4 DNAs ${ }^{40,44,49}$ (Figure 1A-C). The relatively low affinity of DHX36 for C9-repeat G4 DNA might in part explain the lack of a robust effect on C9-repeat transcript levels in cells following DHX36 KD or overexpression. In addition, T7 polymerase in vitro is prone to early transcription termination ${ }^{78}$ and as such may be less efficient than RNA polymerase complexes at resolving RNA structures and generating complete transcripts in cells. Future work using patient-derived cells harboring greater repeat lengths (which DHX36 may have greater affinity for) will be necessary to more fully characterize the potential for DHX36 to modulate C9-repeat transcription in patients.

DHX36 binds to C9-repeat RNA in a G4 specific manner both in vitro and in studies using human cell and mouse spinal cord lysates ${ }^{6,51,79}$. Depletion of DHX36 decreases C9RAN translation and this decrease occurs across all reading frames and is dependent on the length of the repeats (Figures 2-4). Similar results are seen for CGG repeats capable of supporting RAN translation and folding into G4 structures. This suggests that RAN translation initiation or elongation could be significantly influenced by 
both RNA binding protein recognition and resolution of repeat RNA secondary structures. This idea is supported by the finding that a helicase dead form of DHX36 failed to influence RAN translation of C9-repeat RNAs. It is also consistent with prior studies implicating RNA helicases such as DDX3X and the elF4A helicase cofactors elF4B and elF4H as modifiers of RAN translation at both $C G G$ and $\mathrm{G}_{4} \mathrm{C}_{2}$ repeats $^{33,36}$.

In addition, depletion of DHX36 precluded the augmentation of RAN translation typically observed in response to stress (Figure 6) ) $^{29,30,80}$. DHX36 is a component of stress granules and plays an active role in regulating the cellular stress response ${ }^{81-83}$. Indeed, $\mathrm{KD}$ or $\mathrm{KO}$ of $\mathrm{DHX} 36$ is sufficient to trigger stress granule formation without application of an exogenous stressor ${ }^{53}$. How exactly loss of DHX36 precludes this upregulation is not clear. ISR activation augments RAN translation at least in part by lowering initiation codon fidelity requirements ${ }^{29,31}$. If $\mathrm{DHX} 36$ is specifically influencing elongation through the repeat, then its depletion may slow translation due to ribosomal stalling within the repeats despite continued enhanced initiation. Alternatively, $\mathrm{G}_{4} \mathrm{C}_{2}$ repeats also support a 5' $M^{7} G$ cap independent "IRES-like" RAN initiation mechanism that is enhanced by ISR activation ${ }^{30,84-86}$. DHX36 could play an active role in generating this structure and allowing for internal ribosome entry. A deeper understanding of RNA structure/function relationships as they apply to RAN translation will be needed to determine which of these mechanisms (or both) is likely to explain how DHX36 loss impacts RAN translation at both $\mathrm{CGG}$ and $\mathrm{G}_{4} \mathrm{C}_{2}$ repeats.

This study has some limitations. It largely relies on reporter assays using transiently transfected plasmids or in vitro transcribed linear RNA. RAN translation from the endogenous locus of C9 might involve very large RNA from longer repeats and the exact nature of the RAN translated transcripts in $\mathrm{C} 9$ patient neurons remains unclear. In particular, endogenous RNAs may form a combination of dynamic secondary structures including hairpins and $\mathrm{G} 4 \mathrm{~s}$, which complicate the potential effects on both RNA mediated toxicity and RAN translation. Further studies using endogenous systems such as C9 FTD/ALS patient iPSC derived neurons and rodent that harbor larger repeats will 
be needed to confirm the roles of DHX36 in endogenous repeat transcription, RAN translation, and toxicity derived from the endogenous repeat.

In sum, this study provides evidence that $\mathrm{DHX} 36$ can influence RAN translation of $\mathrm{G}_{4} \mathrm{C}_{2}$ repeats both basally and in response to stress pathways. These studies suggest that control of G4 formation at the DNA and RNA levels and modulation of G4 resolving helicases such as DHX36 are candidate therapeutic strategies and targets for $\mathrm{G}$ rich repeat-associated neurological diseases.

\section{METHODS:}

\section{Electrophoretic mobility shift assays}

62.5 pg of 5'- IRDye 800 labeled C9 or scrambled oligonucleotides (Table 1) were synthesized (Integrated DNA Technologies, Inc.) were heated in nuclease-free water in the presence of $\mathrm{KCl}(100 \mathrm{mM})$ starting at $98^{\circ} \mathrm{C}$ and decreasing $10^{\circ} \mathrm{C}$ every two min, ending at $28^{\circ} \mathrm{C}$. As a control, $62.5 \mathrm{pg}$ of $\mathrm{C} 9$ oligonucleotides were heated and cooled as above in the absence of $\mathrm{KCl}, 3.75 \mathrm{pg}$ of each oligonucleotide were incubated at $37^{\circ} \mathrm{C}$ for $30 \mathrm{~min}$ in binding buffer (75 mM EDTA, 40.6 mM Tris-Acetate $\mathrm{pH}$ 7.8, $40.6 \mathrm{mM}$ $\mathrm{NaCl}, 1.21 \mathrm{mM} \mathrm{MgCl}_{2}, 8.1 \%$ glycerol, 0.0065\% lactalbumin, 2-mercaptoethanol, 0.16x protease inhibitor cocktail (Roche), $0.12 \mathrm{mg} / \mathrm{mL}$ leupeptin) with varying concentrations of $\operatorname{rDHX36}(7.4,4.5,1.7,1.1$, or $0 \mathrm{nM})$. Additional volumes of buffer were added to the $4.5,1.7,1.1$, or $0 \mathrm{nM}$ reactions so as to have equal buffer concentrations in all reactions. Glycerol (16\% final) was added to the samples, and 3 pg of DNA were loaded per well onto a 10\% non-denaturing PAGE. The samples were electrophoresed for $5 \mathrm{hrs}$ at $120 \mathrm{~V}$ in the dark. Each EMSA was performed in triplicate and analyzed using a LiCor Odyssey imager. Percent bound was determined by densitometry measurements in ImageStudio using the following equation: percent bound = (bound DNA / total DNA) $\mathrm{x}$ 100. Triplicate values were averaged and plotted with GraphPad Prism using a nonlinear regression (curve fit) function.

\section{In vitro transcription assay}


A HiScribe $^{\mathrm{TM}} \mathrm{T7}$ Quick High Yield RNA Synthesis Kit (New England Bio Labs, Cat.\# E2050S) was used with $1 \mu \mathrm{g}$ of a $\mathrm{GA}_{70}$ or AUG-NLuc linearized plasmid as template ${ }^{29}$. The reactions were transcribed for $15 \mathrm{hrs}$ at $37^{\circ} \mathrm{C}$ in the presence of absence of DHX36 (0 or $6 \mathrm{nM}$ ). An additional volume of DHX36 storage buffer was added to reactions without DHX36 so as to have equal buffer concentrations in all reactions. The resulting transcripts were treated with DNase for $20 \mathrm{~min}$ at room temperature and then isolated using Micro Bio-Spin ${ }^{\mathrm{TM}} 6$ Columns (BioRad, Cat.\# 732-6221). $0.75 \mu \mathrm{g}$ of RNA transcripts were mixed with $2 X$ formamide buffer (95\% deionized formamide, $0.025 \%$ bromophenol blue, $5 \mathrm{mM}$ EDTA) and heated at $95^{\circ} \mathrm{C}$ for $5 \mathrm{~min}$. The samples were resolved in a $7.5 \%$ denaturing-8M urea PAGE for 20 min at $2 \mathrm{~W}$ and then 45 minutes at $20 \mathrm{~W}$. The gels were subsequently soaked in SYBR Gold nucleic acid stains (ThermoFisher, Cat.\# S11494) for 20 min at RT and imaged using a BIO-Rad Gel Docs $^{\mathrm{TM}} \mathrm{XR}+$ and quantified using densitometry software. Densitometry values for the top third of the gel were divided by total value for each lane. Values for total densitometry readings for each lane were also taken.

\section{RNA synthesis}

pcDNA3.1(+)/NLuc-3xF and pcDNA3.1(+)/FF were linearized by PspOMl and Xbal restriction enzymes respectively and recovered using DNA Clean and Concentrator-25 kits (Zymo Research, Cat\# D4033). $\mathrm{m}^{7} \mathrm{G}$-capped and poly-adenylated RNAs were transcribed in vitro from these plasmids using HiScribe T7 ARCA mRNA Kit, with polyA tailing (NEB, Cat\# E2065S) following the manufacturer's instructions and recovered using RNA Clean and Concentrator-25 kits (Zymo Research, Cat\# R1017). The integrity and size of all transcribed RNAs were confirmed by denaturing formaldehyde and formamide agarose gel electrophoresis.

\section{Cell culture, transfection, qRT-PCR, and drug treatment}

Jurkat T1-28/11 and HeLa 15/25 cells were cultured and passaged at $37^{\circ} \mathrm{C}, 5 \% \mathrm{CO}_{2}$. Jurkat T1-28/11 cells were maintained in Roswell Park Memorial Institute (RPMI) 1640 
Medium supplemented with $10 \%$ fetal bovine serum (FBS). HeLa $15 / 25$ cells were maintained in Dulbecco's modified Eagle Medium (DMEM) supplemented with 10\% FBS, $1 \%$ non-essential amino acids, $3 \mu \mathrm{g} / \mathrm{ml}$ blasticidine, and $250 \mathrm{ug} / \mathrm{ml}$ zeocin. To induce DHX36 knockdown, HeLa 15 and HeLa 25 were both treated with daily changed media contained $1 \mathrm{ug} / \mathrm{ml}$ doxycycline (doxy.) for 4 days.

For transfection and luciferase assay in Jurkat cells, cells were plated in 24-well plates at $6 \times 10^{5}$ cells/well in $500 \mu \mathrm{l}$ media. Reverse transfection by using TransIT-Jurkat transfection reagent (Mirus, Cat.\# MIR 2124) was done after cells plating. Cells were co-transfected with $250 \mathrm{ng} /$ well of pcDNA(+)-NLuc-3xFLAG plasmids developed from Kearse et al. and Green et al. and $250 \mathrm{ng} /$ well of pGL4.13 firefly luciferase plasmid as transfection control ${ }^{29,69}$. Mixed plasmids and reagents were added drop-wise in cultured cells after 30 min incubation at room temperature, then the plate was gently shaken for $1 \mathrm{~min}$. Luciferase assays were performed $48 \mathrm{hrs}$ after plasmid transfection. Cells from each well were collected in microcentrifuge tube and media was removed after $400 \mathrm{rpm}$ centrifuge for $5 \mathrm{~min}$. Then cells from each tube were lysed with $60 \mu \mathrm{L}$ of Glo Lysis Buffer 1X (Promega, Cat.\# E2661) and were vortexed for $5 \mathrm{sec}$. In opaque white 96-well plates, from $60 \mu \mathrm{L}$ of cell lysate, $25 \mu \mathrm{L}$ of cell lysate was distributed to mix with $25 \mu \mathrm{L}$ of Nano-Glo Luciferase Assay System (Promega, Cat.\# N1120), and another $25 \mu \mathrm{L}$ of cell lysate was mixed with $25 \mu \mathrm{L}$ of ONE-Glo Luciferase Assay System (Promega, Cat.\# E6130). The plate was placed on a shaker for 5 min in the dark. Luciferase activity in each well was obtained by luminescence measurements. All reagents and experiments are presented at room temperature.

For transfection and luciferase assay in HeLa cells, cells were plated in 96-well plates at $2.5 \times 10^{5} \mathrm{cells} /$ well in $100 \mu \mathrm{l}$ media. $24 \mathrm{hrs}$ after plating, cells were co-transfected with 50 $\mathrm{ng} /$ well of pcDNA(+)-NLuc-3xFLAG plasmids, and $50 \mathrm{ng} / \mathrm{well}$ of $\mathrm{pGL} 4.13$ firefly luciferase plasmid as transfection control. Transfection was done by adding Viafect transfection reagent (Promega, Cat\# E4981) with mixed plasmids drop-wise in cultured cells after $10 \mathrm{~min}$ incubation at room temperature then gently shaking the plate for 1 min. Plasmid DNA and C9-repeat RNA co-transfection were done by forward transfection of published DNA plasmid expressing empty vector, WT, or E335A 
DHX36 $6^{41}$ in HeLa cells seeded at $2.5 \times 10^{5}$ cells/well in $100 \mu \mathrm{l}$ media. After $24 \mathrm{hrs}$, in vitro synthesized C9-RNA and pcDNA-FF RNA were co-transfected at $50 \mathrm{ng} /$ well each into the well by Viafect transfection reagent (Promega, Cat\# E4981) as described above. Following luciferase assays were performed $24 \mathrm{hrs}$ after C9-repeat DNA plasmids or RNA transfection, as described by Kearse et al69.

For qRT-PCR assays, after HeLa cells were plated and transfected as described above, experiments were performed as described by Linsalata et $\mathrm{al}^{33}$.

For C9RAN reporter luciferase analysis following stress activation, after 4 days of doxy. treatment in HeLa 15/25 cells, cells were seeded and transfect for 19 hrs then followed by 5 hrs treatment of $2 \mu \mathrm{M}$ Thapsigargin $(\mathrm{Tg})$.

\section{Immunoblot and antibodies}

In a 12-well plate, HeLa 15/25 cells were rinsed with $500 \mu \mathrm{L}$ cold $1 \mathrm{X}$ PBS twice then lysed in $300 \mu \mathrm{L}$ RIPA buffer with protease inhibitor (120 $\mu \mathrm{L}$ for 24 -well plates) for $30 \mathrm{~min}$ at a $4^{\circ} \mathrm{C}$ shaker. Lysates were homogenized by passing through a $28 \mathrm{G}$ syringe 8 times, mixed with $6 \mathrm{X}$ sample buffer with a final of $2 \% \mathrm{~B}-\mathrm{ME}$, denatured at $95^{\circ} \mathrm{C}$ for $10 \mathrm{~min}$, and stored at $-20^{\circ} \mathrm{C}$. Protein samples were standardized by BCA assay for equal total protein loading. $20 \mu \mathrm{L}$ of equal total protein sample was loaded in each well of a $10 \%$ SDS-PAGE. All primary antibodies applied for Western Blot were used at 1:1000 in 5\% non-fat dairy milk (wt/vol) and $0.1 \%$ Tween-20 (vol/vol) in TBS except anti-puromycin at 1:5000. Monoclonal mouse anti-DHX36 antibody was generated at $2.57 \mu \mathrm{g} / \mathrm{\mu l}^{41}$, monoclonal mouse anti-FLAG antibody was from Sigma (clone M2, Cat\#F1804), mouse anti-GFP was from Roche (Cat\# 11814460001), monoclonal mouse anti-GAPDH was from Santa Cruz Biotechnology (clone 6C5, Cat\# sc-32233), mouse anti-puromycin 12D10 was from Millipore (Cat\# MABE434).

\section{Jurkat cell line generation}


The DHX36 gRNAs (T1, T2, and T10) were designed to target exonic regions of DHX36/G4R1 (Gene ID: 170506) in order to disrupt all the gene products (Supplemental Figure 3). The gRNA T1 (AAGTACGATATGACTAACAC) was evaluated to be the most effective by nucleotide mismatching assay in the cell pool examination (31.2\% cleavage efficiency) and was utilized for generation of single cell clones. Cleavage efficiency was determined by sequencing trace analysis with the online tool TIDE (https://tide-calculator.nki.nl/). Clones were identified and confirmed using Sanger Sequencing of PCR and RT-PCR productions (Supplemental Figure 3) and western blot analysis (Figure 3, A)

\section{In vitro translation assays}

Preparation of cell lysate, hypertonic lysis buffer, and translation buffer were followed by Linsalata et al ${ }^{33}$. Jurkat cells were centrifuged, and rinsed 3 times with PBS (pH 7.4). Hypotonic lysis buffer that contained 10 mM HEPES-KOH (pH 7.6), 10 mM KOAc, 0.5 mM Mg2OAc, 5 mM DTT, and EDTA-free protease inhibitor was added to cells pellet on ice to swollen the cells for 30 minutes. Then cells were mechanically lysed by 20 strokes in a $27 \mathrm{G}$ syringe and followed by another 30 minutes of incubation on ice. The supernatant from the cell lysate was collected by centrifuging the cell lysate at 10,000 $\mathrm{g}$ for $10 \mathrm{~min}$ at $4^{\circ} \mathrm{C}$ and further diluted in lysis buffer to $8.0 \mathrm{ug} / \mathrm{ul}$ using a modified Bradford protein quantification assay (Bio-Rad), flash-frozen in liquid $\mathrm{N}_{2}$, and stored at $80^{\circ} \mathrm{C}$. The lysates were added to the translation buffer that with final concentrations of $20 \mathrm{mM}$ HEPES-KOH (pH 7.6), 44 mM KOAc, 2.2 mM Mg2AOc, 2 mM DTT, 20 mM creatine phosphate (Roche), $0.1 \mathrm{ug} / \mathrm{ul}$ creatine kinase (Roche), $0.1 \mathrm{mM}$ spermidine, and on average $0.1 \mathrm{mM}$ of each amino acid.

For in vitro translation assays, $40 \mathrm{fmol}$ of RNA was added to lysate which protein concentration at $8 \mathrm{ug} / \mathrm{ul}$ of $10 \mathrm{ul}$ per reaction. After incubation at $30^{\circ} \mathrm{C}$ for $120 \mathrm{~min}, 25 \mathrm{ul}$ room temperature Glo Lysis Buffer (Promega) was added to the reaction to incubate for $5 \mathrm{~min}$ at room temperature. With the Nano-Glo Dual-luciferase system, 25 ul of this mixture was added 25 ul of the ONE-Glo ${ }^{\text {TM }}$ EX reagent following 25 ul of NanoDLR Stop \& Glo reagent (Promega). All mixtures were incubated in opaque white 96-well plates on a rocking shaker in the dark for 5 min before quantifying the luminescence. 


\section{Measuring protein synthesis by puromycin incorporation}

Nascent Global translation was monitored by the surface sensing of translation (SUnSET) method ${ }^{58}$. After seeding HeLa cells as described above in a 24-well plate format, $48 \mathrm{hrs}$ later, cells were incubated with fresh media containing $10 \mu \mathrm{g} / \mathrm{ml}$ of puromycin for $10 \mathrm{~min}$ at room temperature. Cells were then placed on ice and washed with ice-cold PBS, prior to lysis in $100 \mu \mathrm{L}$ RIPA buffer containing protease inhibitor.

\section{Statistical methods}

Statistical analysis was performed using GraphPad Prism8. For comparison of NLuc and FFLuc reporter luciferase activity, one-way ANOVAs were performed to confirm statistical difference between control and experimental groups. Two-way ANOVA was performed to confirm the statistical difference on FFLuc signal from the treatment of Thapsigargin between different groups of control and experimental conditions. Post-hoc Student's $t$ tests were then performed with Bonferroni correction for multiple comparisons and Welch's correction for unequal variance. All studies represent at least three independently replicated experiments. All bar graphs include a standard deviation error bar and each independent replicate. Exact $\mathrm{N}$ for each sample and analysis performed are noted in the figure legend.

\section{Acknowledgements}

We thank everyone in the Todd lab and the Smaldino lab for thoughtful feedback and discussion on this project. Jiou Wang provided initial $\mathrm{G}_{4} \mathrm{C}_{2}$ repeat plasmids to the Smaldino Lab.

\section{Funding:}

This work was funded by the NIH (R15 AG067291 to PJS, T32GM008136 to HMR, RO1GM101192 to Y-HW, P50HD104463, R01NS099280 and R01NS086810 to PKT), VA (BLRD BX004842 and BX003231 to PKT), the University of Michigan (Cellular and Molecular Biology Graduate program and the Chia-Lun Lo Fellowship to Y-JT), Ball 
State University (Startup Funds and Junior Faculty ASPIRE grant to PJS, Graduate Student ASPIRE grant to AER), and Amyotrophic Lateral Sclerosis Association Grant 18-IIA-406 to PJS.

\section{COI:}

PKT served as a paid consultant for Denali Therapeutics, holds a joint patent with lonis Therapeutics, and receives publishing royalties from UpToDate. None of these are directly relevant to his role on this manuscript and none of these organizations have any role in the conception, preparation or editing of this manuscript. All other authors declare no conflicts of interest. 


\section{Reference:}

1. Renton, A. E. et al. A Hexanucleotide Repeat Expansion in C9ORF72 Is the Cause of Chromosome 9p21-Linked ALS-FTD. Neuron 72, 257-268 (2011).

2. DeJesus-Hernandez, M. et al. Expanded GGGGCC Hexanucleotide Repeat in Noncoding Region of C9ORF72 Causes Chromosome 9p-Linked FTD and ALS. Neuron 72, 245256 (2011).

3. Van Mossevelde, S., van der Zee, J., Cruts, M. \& Van Broeckhoven, C. Relationship between C9orf72 repeat size and clinical phenotype. Current Opinion in Genetics and Development (2017). doi:10.1016/j.gde.2017.02.008

4. Byrne, S., Heverin, M., Elamin, M., Walsh, C. \& Hardiman, O. Intermediate repeat expansion length in C9orf72 may be pathological in amyotrophic lateral sclerosis. Amyotroph. Lateral Scler. Front. Degener. (2014). doi:10.3109/21678421.2013.838586

5. Umoh, M. E. et al. Comparative analysis of C9orf72 and sporadic disease in an ALS clinic population. Neurology (2016). doi:10.1212MNL.0000000000003067

6. Haeusler, A. R. et al. C9orf72 nucleotide repeat structures initiate molecular cascades of disease. Nature 507, 195-200 (2014).

7. Donnelly, C. J. et al. RNA Toxicity from the ALS/FTD C9ORF72 Expansion Is Mitigated by Antisense Intervention. Neuron 80, 415-428 (2013).

8. Conlon, E. G. et al. The C9ORF72 GGGGCC expansion forms RNA G-quadruplex inclusions and sequesters hnRNP H to disrupt splicing in ALS brains. Elife 5, (2016).

9. Fratta, P. et al. C9orf72 hexanucleotide repeat associated with amyotrophic lateral sclerosis and frontotemporal dementia forms RNA G-quadruplexes. Sci. Rep. (2012). doi:10.1038/srep01016

10. Su, Z. et al. Discovery of a Biomarker and Lead Small Molecules to Target r(GGGGCC)Associated Defects in c9FTD/ALS. Neuron (2014). doi:10.1016/j.neuron.2014.07.041

11. Zhou, B., Liu, C., Geng, Y. \& Zhu, G. Topology of a G-quadruplex DNA formed by C9orf72 hexanucleotide repeats associated with ALS and FTD. Sci. Rep. (2015). doi:10.1038/srep16673 
12. Zamiri, B., Reddy, K., Macgregor, R. B. \& Pearson, C. E. TMPyP4 porphyrin distorts RNA G-quadruplex structures of the disease-associated r(GGGGCC)n repeat of the C9orf72 gene and blocks interaction of RNAbinding proteins. J. Biol. Chem. (2014). doi:10.1074/jbc.C113.502336

13. Simone, R. et al. G-quadruplex-binding small molecules ameliorate C9orf72 FTD / ALS pathology in vitro and in vivo. EMBO Mol. Med. 10, 22-31 (2018).

14. Mendoza, O., Bourdoncle, A., Boulé, J. B., Brosh, R. M. \& Mergny, J. L. G-quadruplexes and helicases. Nucleic Acids Research (2016). doi:10.1093/nar/gkw079

15. Maizels, N. G4-associated human diseases. EMBO Rep. (2015). doi:10.15252/embr.201540607

16. Rhodes, D. \& Lipps, H. J. Survey and summary G-quadruplexes and their regulatory roles in biology. Nucleic Acids Research (2015). doi:10.1093/nar/gkv862

17. Biffi, G., Tannahill, D., McCafferty, J. \& Balasubramanian, S. Quantitative visualization of DNA G-quadruplex structures in human cells. Nat. Chem. (2013). doi:10.1038/nchem.1548

18. Henderson, A. et al. Detection of G-quadruplex DNA in mammalian cells. Nucleic Acids Res. (2014). doi:10.1093/nar/gkt957

19. Hänsel-Hertsch, R. et al. G-quadruplex structures mark human regulatory chromatin. Nat. Genet. (2016). doi:10.1038/ng.3662

20. Chambers, V. S. et al. High-throughput sequencing of DNA G-quadruplex structures in the human genome. Nat. Biotechnol. (2015). doi:10.1038/nbt.3295

21. Bedrat, A., Lacroix, L. \& Mergny, J. L. Re-evaluation of G-quadruplex propensity with G4Hunter. Nucleic Acids Res. (2016). doi:10.1093/nar/gkw006

22. Huppert, J. L. \& Balasubramanian, S. Prevalence of quadruplexes in the human genome. Nucleic Acids Res. (2005). doi:10.1093/nar/gki609

23. Huppert, J. L. \& Balasubramanian, S. G-quadruplexes in promoters throughout the human genome. Nucleic Acids Res. (2007). doi:10.1093/nar/gkl1057

24. Maltby, C. J. et al. A 5' UTR GGN repeat controls localisation and translation of a potassium leak channel mRNA through G-quadruplex formation. Nucleic Acids Res. 
(2020). doi:10.1093/nar/gkaa699

25. Shi, Y. et al. Haploinsufficiency leads to neurodegeneration in C9ORF72 ALS/FTD human induced motor neurons. Nat. Med. 24, (2018).

26. Shi, K. Y. et al. Toxic PRn poly-dipeptides encoded by the C9orf72 repeat expansion block nuclear import and export. Proc. Natl. Acad. Sci. U. S. A. (2017). doi:10.1073/pnas.1620293114

27. Taylor, J. P. A PR plug for the nuclear pore in amyotrophic lateral sclerosis. Proceedings of the National Academy of Sciences of the United States of America (2017). doi:10.1073/pnas.1621085114

28. Rodriguez, C. M. \& Todd, P. K. New pathologic mechanisms in nucleotide repeat expansion disorders. Neurobiology of Disease (2019). doi:10.1016/j.nbd.2019.104515

29. Green, K. M. et al. RAN translation at C9orf72-associated repeat expansions is selectively enhanced by the integrated stress response. Nat. Commun. 8, (2017).

30. Cheng, W. et al. C9ORF72 GGGGCC repeat-associated non-AUG translation is upregulated by stress through elF2 $\alpha$ phosphorylation. Nat. Commun. (2018). doi:10.1038/s41467-017-02495-z

31. Tabet, R. et al. CUG initiation and frameshifting enable production of dipeptide repeat proteins from ALS/FTD C9ORF72 transcripts. Nat. Commun. 9, 1-14 (2018).

32. Sonobe, Y. et al. Translation of dipeptide repeat proteins from the C9ORF72 expanded repeat is associated with cellular stress. Neurobiol. Dis. (2018).

doi:10.1016/j.nbd.2018.05.009

33. Linsalata, A. E. et al. DDX 3X and specific initiation factors modulate FMR 1 repeatassociated non-AUG-initiated translation . EMBO Rep. 1-18 (2019). doi:10.15252/embr.201847498

34. Cheng, W. et al. CRISPR-Cas9 Screens Identify the RNA Helicase DDX3X as a Repressor of C9ORF72 (GGGGCC)n Repeat-Associated Non-AUG Translation. Neuron 104, 885-898.e8 (2019).

35. Yamada, S. B. et al. RPS25 is required for efficient RAN translation of C9orf72 and other neurodegenerative disease-associated nucleotide repeats. Nat. Neurosci. (2019). 
doi:10.1038/s41593-019-0455-7

36. Goodman, L. D. et al. elF4B and elF4H mediate GR production from expanded G4C2 in a Drosophila model for C9orf72-associated ALS. Acta Neuropathol. Commun. (2019). doi:10.1186/s40478-019-0711-9

37. Westergard, T. et al. Repeat-associated non- AUG translation in C9orf72- ALS / FTD is driven by neuronal excitation and stress. EMBO Mol. Med. (2019). doi:10.15252/emmm.201809423

38. Zu, T. et al. Metformin inhibits RAN translation through PKR pathway and mitigates disease in C9orf72 ALS/FTD mice. Proc. Natl. Acad. Sci. U. S. A. 117, 18591-18599 (2020).

39. Schult, P. \& Paeschke, K. The DEAH helicase DHX36 and its role in G-quadruplexdependent processes. Biol. Chem. 402, 581-591 (2020).

40. Creacy, S. D. et al. G4 resolvase 1 binds both DNA and RNA tetramolecular quadruplex with high affinity and is the major source of tetramolecular quadruplex G4-DNA and G4RNA resolving activity in HeLa cell lysates. J. Biol. Chem. (2008). doi:10.1074/jbc.M806277200

41. Vaughn, J. P. et al. The DEXH protein product of the DHX36 gene is the major source of tetramolecular quadruplex G4-DNA resolving activity in HeLa cell lysates. J. Biol. Chem. (2005). doi:10.1074/jbc.C500348200

42. Booy, E. P. et al. RNA helicase associated with AU-rich element (RHAU/DHX36) interacts with the 3'-tail of the long non-coding RNA BC200 (BCYRN1). J. Biol. Chem. 291, 5355-5372 (2016).

43. Booy, E. P. et al. The RNA helicase RHAU (DHX36) unwinds a G4-quadruplex in human telomerase RNA and promotes the formation of the P1 helix template boundary. Nucleic Acids Res. (2012). doi:10.1093/nar/gkr1306

44. Giri, B. et al. G4 Resolvase 1 tightly binds and unwinds unimolecular G4-DNA. Nucleic Acids Res. (2011). doi:10.1093/nar/gkr234

45. Booy, E. P. et al. The RNA helicase RHAU (DHX36) suppresses expression of the transcription factor PITX1. Nucleic Acids Res. (2014). doi:10.1093/nar/gkt1340 
46. Huang, W. et al. Yin Yang 1 contains G-quadruplex structures in its promoter and 5'-UTR and its expression is modulated by G4 resolvase 1. Nucleic Acids Res. (2012). doi:10.1093/nar/gkr849

47. Nie, J. et al. Post-transcriptional Regulation of Nkx2-5 by RHAU in Heart Development. Cell Rep. (2015). doi:10.1016/j.celrep.2015.09.043

48. Kim, H. N. et al. Histone deacetylase inhibitor MS-275 stimulates bone formation in part by enhancing Dhx36-mediated TNAP transcription. J. Bone Miner. Res. (2011). doi:10.1002/jbmr.426

49. Smaldino, P. J. et al. Mutational dissection of telomeric DNA binding requirements of G4 Resolvase 1 shows that G4-structure and certain 3'-tail sequences are sufficient for tight and complete binding. PLoS One (2015). doi:10.1371/journal.pone.0132668

50. Sexton, A. N. \& Collins, K. The 5' Guanosine Tracts of Human Telomerase RNA Are Recognized by the G-Quadruplex Binding Domain of the RNA Helicase DHX36 and Function To Increase RNA Accumulation. Mol. Cell. Biol. (2011). doi:10.1128/mcb.0103310

51. McRae, E. K. S. et al. Human DDX21 binds and unwinds RNA guanine quadruplexes. Nucleic Acids Res. (2017). doi:10.1093/nar/gkx380

52. Booy, E. P., McRae, E. K. S. \& McKenna, S. A. Biochemical characterization of G4 Quadruplex Telomerase RNA unwinding by the RNA helicase RHAU. Methods Mol. Biol. (2015). doi:10.1007/978-1-4939-2214-7_9

53. Sauer, M. et al. DHX36 prevents the accumulation of translationally inactive mRNAs with G4-structures in untranslated regions. Nat. Commun. (2019). doi:10.1038/s41467-019$10432-5$

54. Vester, K. et al. RNAi-mediated knockdown of the Rhau helicase preferentially depletes proteins with a Guanine-quadruplex motif in the 5'-UTR of their mRNA. Biochem.

Biophys. Res. Commun. (2019). doi:10.1016/j.bbrc.2018.11.186

55. Murat, P. et al. RNA G-quadruplexes at upstream open reading frames cause DHX36and DHX9-dependent translation of human mRNAs. Genome Biol. (2018). doi:10.1186/s13059-018-1602-2

56. Chen, M. C. et al. Structural basis of G-quadruplex unfolding by the DEAH/RHA helicase 
DHX36. Nature 558, 465-483 (2018).

57. Iwamoto, F., Stadler, M., Chalupníková, K., Oakeley, E. \& Nagamine, Y. Transcriptiondependent nucleolar cap localization and possible nuclear function of DExH RNA helicase RHAU. Exp. Cell Res. (2008). doi:10.1016/j.yexcr.2008.01.006

58. Schmidt, E. K., Clavarino, G., Ceppi, M. \& Pierre, P. SUnSET, a nonradioactive method to monitor protein synthesis. Nat. Methods 6, 275-277 (2009).

59. Todd, P. K. et al. CGG repeat-associated translation mediates neurodegeneration in fragile $X$ tremor ataxia syndrome. Neuron (2013). doi:10.1016/j.neuron.2013.03.026

60. Krans, A., Kearse, M. G. \& Todd, P. K. Repeat-associated non-AUG translation from antisense CCG repeats in fragile $X$ tremor/ataxia syndrome. Ann. Neurol. (2016). doi:10.1002/ana.24800

61. Buijsen, R. A. M. et al. Presence of inclusions positive for polyglycine containing protein, FMRpolyG, indicates that repeat-associated non-AUG translation plays a role in fragile $X$ associated primary ovarian insufficiency. Hum. Reprod. 31, 158-168 (2016).

62. Sellier, C. et al. Translation of Expanded CGG Repeats into FMRpolyG Is Pathogenic and May Contribute to Fragile X Tremor Ataxia Syndrome. Neuron (2017). doi:10.1016/j.neuron.2016.12.016

63. Buijsen, R. A. M. et al. FMRpolyG-positive inclusions in CNS and non-CNS organs of a fragile $\mathrm{X}$ premutation carrier with fragile $\mathrm{X}$-associated tremor/ataxia syndrome. Acta Neuropathologica Communications (2014). doi:10.1186/s40478-014-0162-2

64. Hukema, R. K. et al. Reversibility of neuropathology and motor deficits in an inducible mouse model for FXTAS. Hum. Mol. Genet. 24, 4948-4957 (2015).

65. Usdin, K. \& Woodford, K. J. CGG repeats associated with DNA instability and chromosome fragility form structures that block DNA synthesis in vitro. Nucleic Acids Res. (1995). doi:10.1093/nar/23.20.4202

66. Fry, M. \& Loeb, L. A. The fragile $X$ syndrome d(CGG)(n) nucleotide repeats form a stable tetrahelical structure. Proc. Natl. Acad. Sci. U. S. A. (1994). doi:10.1073/pnas.91.11.4950

67. Kettani, A., Kumar, R. A. \& Patel, D. J. Solution structure of a DNA quadruplex containing the fragile $X$ syndrome triplet repeat. J. Mol. Biol. (1995). doi:10.1006/jmbi.1995.0644 
68. Asamitsu, S. et al. CGG repeat RNA G-quadruplexes interact with FMRpolyG to cause neuronal dysfunction in fragile X-related tremor/ataxia syndrome. Sci. Adv. (2021). doi:10.1126/sciadv.abd9440

69. Kearse, M. G. et al. CGG Repeat-Associated Non-AUG Translation Utilizes a CapDependent Scanning Mechanism of Initiation to Produce Toxic Proteins. Mol. Cell 62, 314-322 (2016).

70. Almeida, S. et al. Production of poly(GA) in C9ORF72 patient motor neurons derived from induced pluripotent stem cells. Acta Neuropathologica (2019). doi:10.1007/s00401-01902083-z

71. Jackson, R. J., Hellen, C. U. T. \& Pestova, T. V. The mechanism of eukaryotic translation initiation and principles of its regulation. Nat. Rev. Mol. Cell Biol. 11, 113-127 (2010).

72. Walter, P. \& Ron, D. The unfolded protein response: From stress pathway to homeostatic regulation. Science (2011). doi:10.1126/science.1209038

73. Young, S. K., Baird, T. D. \& Wek, R. C. Translation Regulation of the Glutamyl-prolyltRNA Synthetase Gene EPRS through Bypass of Upstream Open Reading Frames with Noncanonical Initiation Codons. J. Biol. Chem. 291, 10824-10835 (2016).

74. Starck, S. R. et al. Translation from the 5' untranslated region shapes the integrated stress response. Science (80-. ). 351, (2016).

75. Hinnebusch, A. G., Ivanov, I. P. \& Sonenberg, N. Translational control by 5'-untranslated regions of eukaryotic mRNAs. Science (80-. ). 352, 1413-1416 (2016).

76. Simone, R., Fratta, P., Neidle, S., Parkinson, G. N. \& Isaacs, A. M. G-quadruplexes: Emerging roles in neurodegenerative diseases and the non-coding transcriptome. FEBS Letters (2015). doi:10.1016/j.febslet.2015.05.003

77. Schofield, J. P. R., Cowan, J. L. \& Coldwell, M. J. G-quadruplexes mediate local translation in neurons. Biochem. Soc. Trans. (2015). doi:10.1042/BST20150053

78. Brunelle, J. L. \& Green, R. In vitro transcription from plasmid or PCR-amplified DNA. Methods in Enzymology 530, (Elsevier Inc., 2013).

79. Zu, T. et al. RAN proteins and RNA foci from antisense transcripts in C9ORF72 ALS and frontotemporal dementia. Proc. Natl. Acad. Sci. 110, E4968-E4977 (2013). 
80. Westergard, T. et al. Cell-to-Cell Transmission of Dipeptide Repeat Proteins Linked to C9orf72-ALS/FTD. Cell Rep. 17, 645-652 (2016).

81. Chalupníková, K. et al. Recruitment of the RNA helicase RHAU to stress granules via a unique RNA-binding domain. J. Biol. Chem. (2008). doi:10.1074/jbc.M804857200

82. Byrd, A. K. et al. Evidence that G-quadruplex DNA accumulates in the cytoplasm and participates in stress granule assembly in response to oxidative stress. J. Biol. Chem. (2016). doi:10.1074/jbc.M116.718478

83. Yoo, J. S. et al. DHX36 Enhances RIG-I Signaling by Facilitating PKR-Mediated Antiviral Stress Granule Formation. PLoS Pathog. (2014). doi:10.1371/journal.ppat.1004012

84. Stoneley, M. \& Willis, A. E. Cellular internal ribosome entry segments: Structures, transacting factors and regulation of gene expression. Oncogene (2004). doi:10.1038/sj.onc.1207551

85. Komar, A. A. \& Hatzoglou, M. Cellular IRES-mediated translation: The war of ITAFs in pathophysiological states. Cell Cycle (2011). doi:10.4161/cc.10.2.14472

86. Komar, A. A. \& Hatzoglou, M. Internal ribosome entry sites in cellular mRNAs: Mystery of their existence. J. Biol. Chem. 280, 23425-23428 (2005). 
bioRxiv preprint doi: https://doi.org/10.1101/2021.04.25.441260; this version posted April 26, 2021. The copyright holder for this preprint (which was not certified by peer review) is the author/funder, who has granted bioRxiv a license to display the preprint in perpetuity. It is made available under aCC-BY-NC-ND 4.0 International license.

\begin{tabular}{|l|l|l|}
\hline Oligo name & $\mathbf{5}^{\prime}$ label & Sequence (5'-3') \\
\hline$\left(\mathrm{G}_{4} \mathrm{C}_{2}\right)_{5}$-DNA & IRDye 800 & GGGGCCGGGGCCGGGGCCGGGGCCGGGGCCGTTAGAATTTTT \\
\hline Scrambled & IRDye 800 & GCGAGTGCGAGAGCGTGTGCGCGCGTGCGCGAGCGCGTGTGT \\
\hline
\end{tabular}

Table 1: DNA oligonucleotides used in this study. 
bioRxiv preprint doi: https://doi.org/10.1101/2021.04.25.441260; this version posted April 26, 2021. The copyright holder for this preprint (which was not certified by peer review) is the author/funder, who has granted bioRxiv a license to display the preprint in perpetuity. It is made available under aCC-BY-NC-ND 4.0 International license.

\section{Table 1}

DNA oligonucleotides used in EMSA studies. 
Figure 1

A

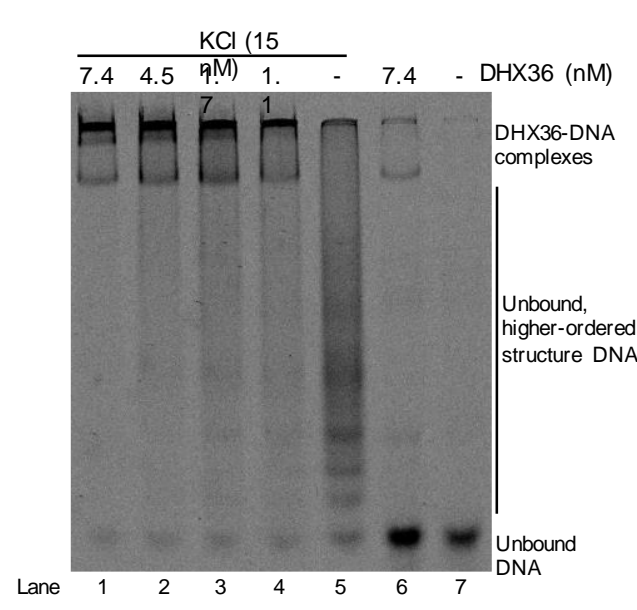

B

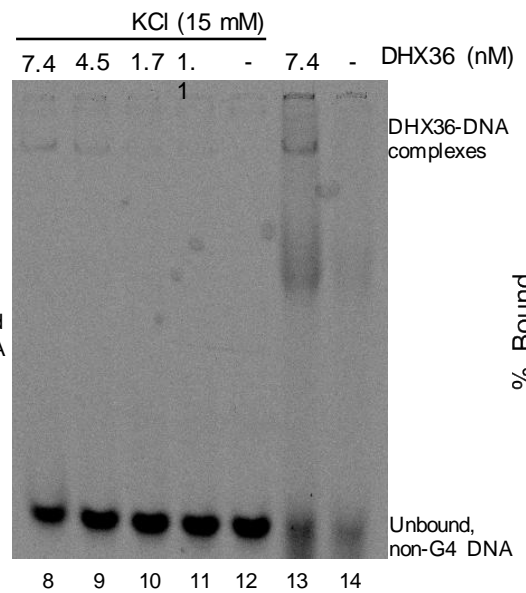

C

$-\mathrm{G}_{4} \mathrm{C}_{2}$-DNA

- Scrambled DNA

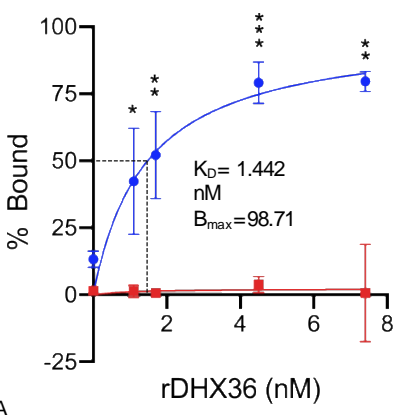

rDHX36 (nM)

D

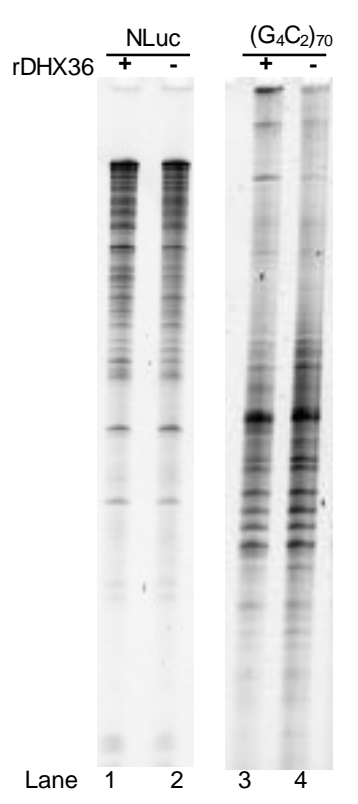

$E$

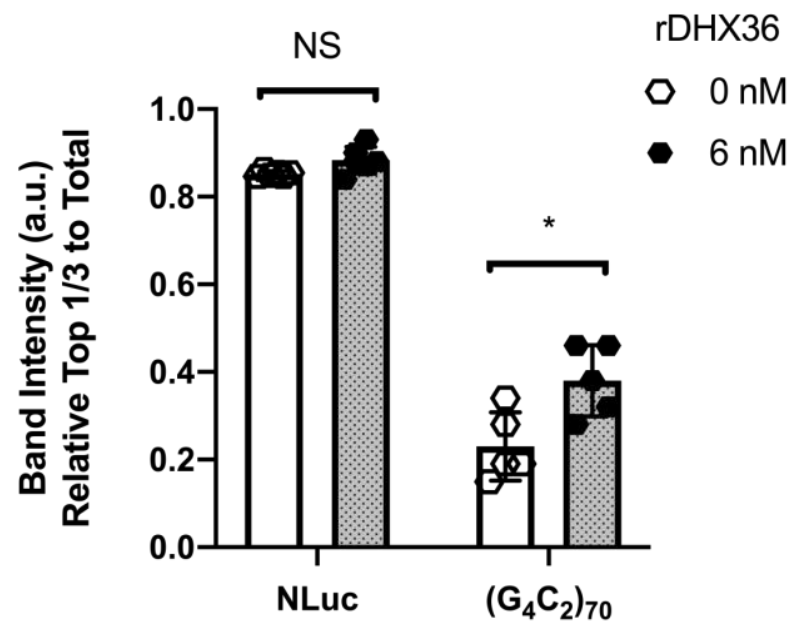

Figure 1: DHX36 binds and enhances transcription of C9-DNA in vitro.

(A) Representative electrophoretic mobility shift assay (EMSA) image. C9 repeat DNA oligonucleotides were heated and cooled in the presence (lanes 1-5) and absence (lanes 6-7) of $\mathrm{KCl}$ to induce or prevent $\mathrm{G} 4$ formation, respectively. DNA was incubated with increasing concentrations of recombinant $\mathrm{DHX} 36$, analyzed with non-denaturing PAGE, and imaged. (B) Representative EMSA image. Scrambled control DNA 
oligonucleotides were heated and cooled in the presence (lanes 1-5) and absence (lanes 6-7) of $\mathrm{KCl}$. DNA was incubated with increasing concentrations of recombinant DHX36, analyzed with non-denaturing PAGE, and imaged. (C) Densiometric quantification of panels $A$ and $B$. The percent bound for each lane was graphed versus the concentration of $D H X 36$. Data in are presented as mean $\pm S D, n=3$. Multiple t-tests for each concentration of protein, ${ }^{*} p=<0.05,{ }^{* *} p<0.01,{ }^{* * *} p<0.001$. (D) T7 polymerase transcript products generated from equal amounts of linearized nanoLuciferase (lanes 1-2) or $\left(\mathrm{G}_{4} \mathrm{C}_{2}\right)_{70}$ plasmids (lanes 3-4) resolved by denaturing PAGE. The gel was stained with SYBR gold nucleic acid stain and imaged. (E) Densiometric quantification of panel D. All signals were first subtracted by the background. Then signal from the top third of the gel was divided by the total signal per lane. Data are presented as $\pm S D$, $\mathrm{n}=5$ (NLuc)-6(G $\mathrm{G}_{4} \mathrm{C}_{2}{ }_{70}$. Two-tailed pair t-test, N.S. = not-significant, ${ }^{*} P<0.05$. 
Figure 2

A

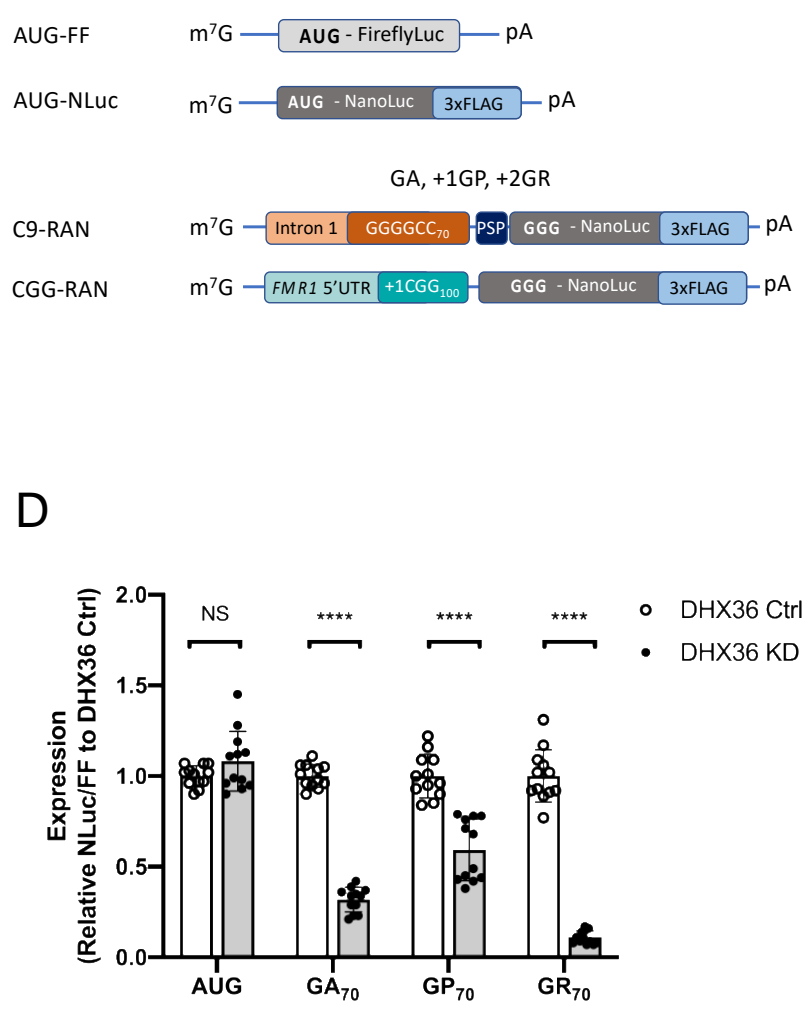

$\mathrm{F}$

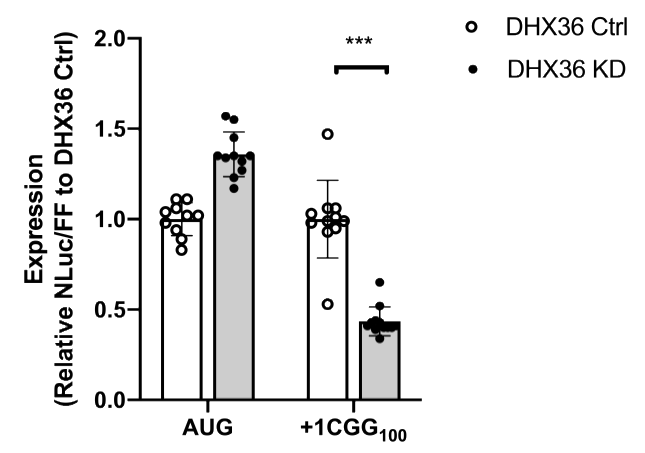

B

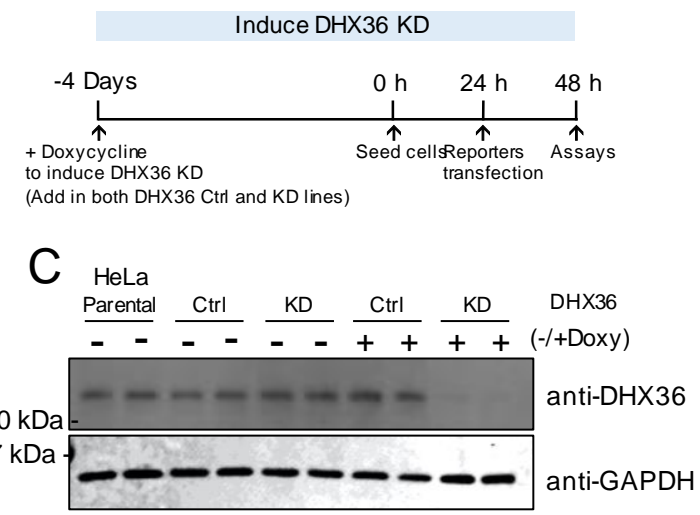

E

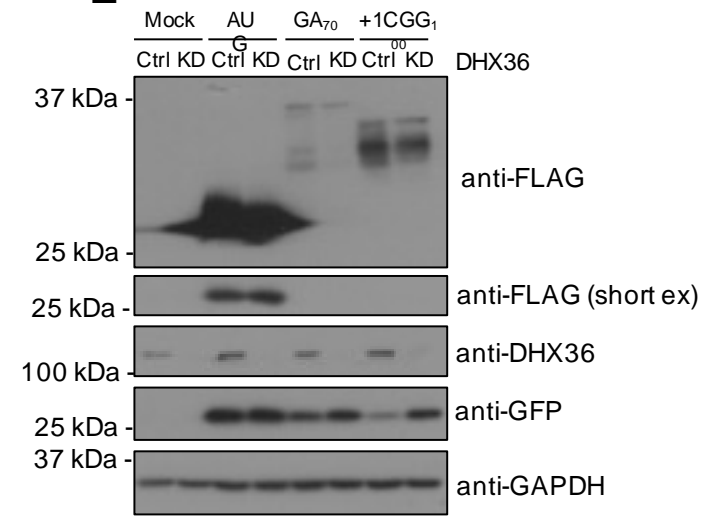

G

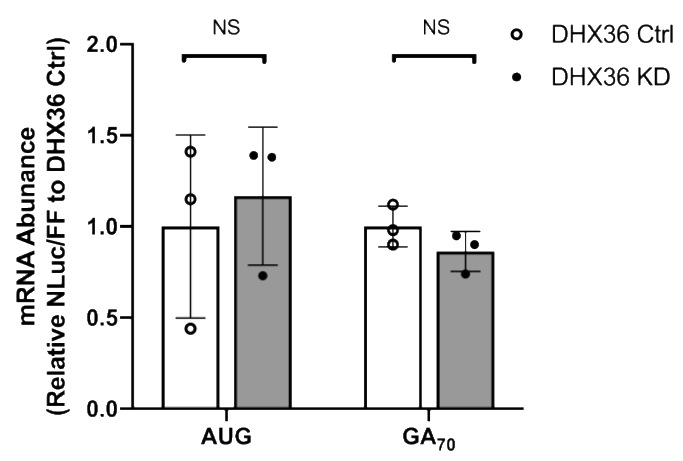

Figure 2: The effect of DHX36 knockdown on C9-RNA and C9RAN reporter expression. (A) Schematic of AUG-FF, AUG-NLuc control, C9-RAN and CGG-RAN luciferase reporters. (B) Experimental timeline for doxycycline treatment and reporter transfection. (C) Immunoblots detecting DHX36 in parental, Ctrl and DHX36 KD HeLa cells with and without doxycycline treatment. (D) Relative expression of AUG and C9RAN translation in GA $(+0)$, GP $(+1)$, and GR $(+2)$ frames with 70 repeats between Ctrl and DHX36 KD HeLa cells. NLuc signal were normalized to AUG-FFluc translation. (E) 
Immunoblot of RAN translation products from 70 repeats of $\mathrm{G}_{4} \mathrm{C}_{2}$ in $\mathrm{GA}$ frame and 100 repeats of CGG in +1 reading frame in Ctrl and DHX36 KD HeLa cells. GFP was blotted as transfection control and GAPDH was blotted as loading control. (F) Expression of $+1 \mathrm{CG}_{100} \mathrm{RAN}$ translation reporters measured by luciferase assay. NLuc signals were normalized to AUG-FFluc signals to compare between Ctrl and DHX36 KD HeLa cells. (G) Abundance of NLuc mRNA from AUG and $G_{70}$ in DHX36 Ctrl and KD HeLa cells. NLuc mRNA were normalized to FF mRNA and compared to DHX36 Ctrl. Data in (D) and $(F)$ are represented as mean $\pm S D, n=9-12$. Data in $(G)$ are mean $\pm S D, n=3$. Twotailed Student's t-test with Bonferroni and Welch's correction, N.S. $=$ not-significant, ${ }^{*} P<$ $0.05 ;{ }^{* *} P<0.01 ;{ }^{* * *} P<0.001 ;{ }^{* * \star} P<0.0001$. 
Figure 3

A

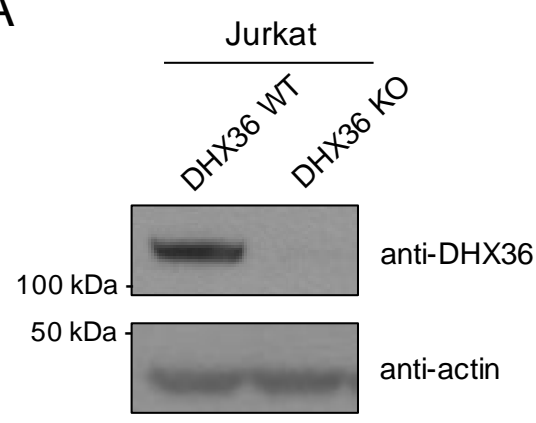

B

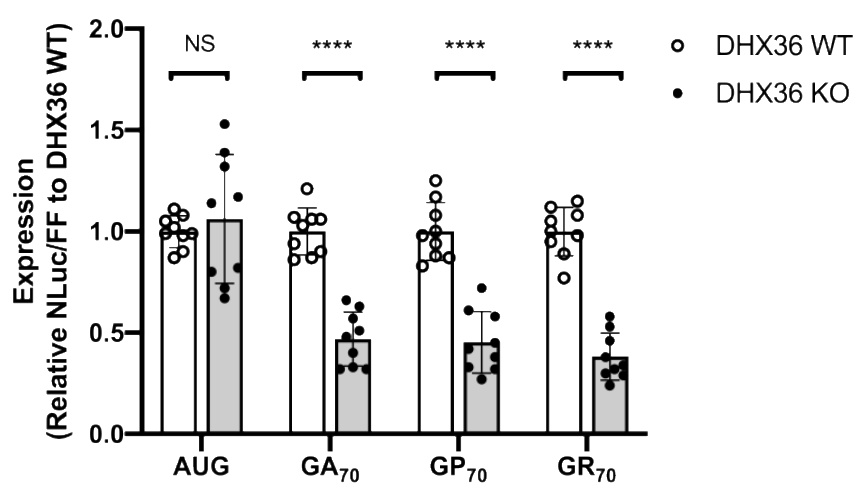

C

DHX36 KO/WT
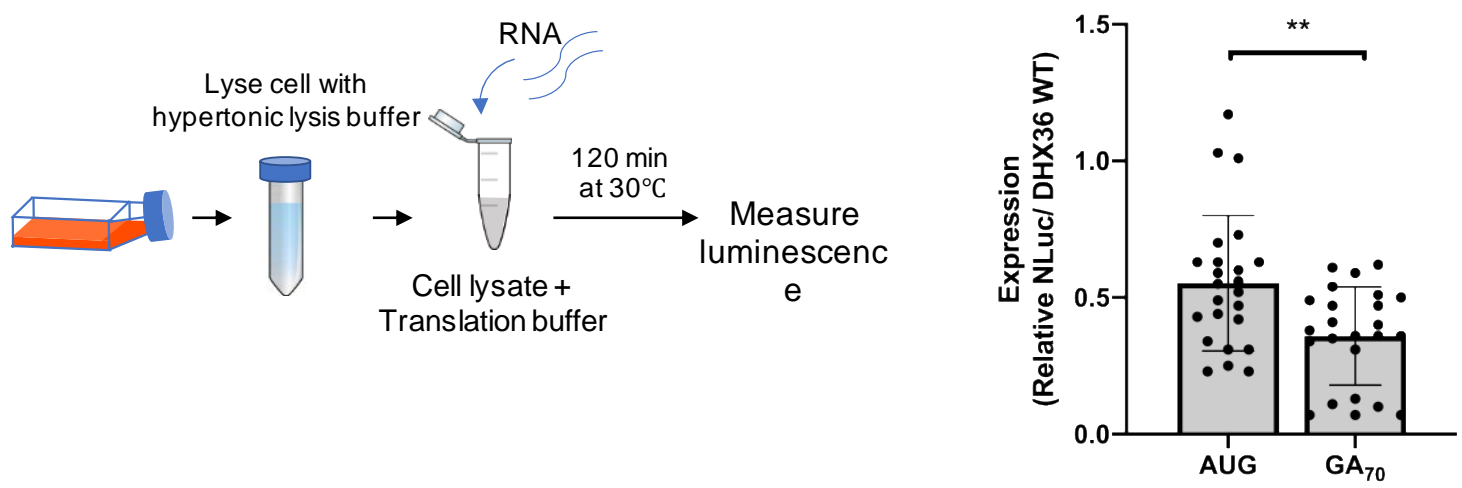

Figure 3: C9RAN reporter expression in DHX36 knockout Jurkat cell lines and in vitro cell lysates. (A) Immunoblots to DHX36 from WT and DHX36 KO Jurkat cells. (B) Relative expression of AUG and C9-RAN translation from $\mathrm{GA}(+0), \mathrm{GP}(+1)$, and $\mathrm{GR}(+2)$ reading frames in WT and DHX36 KO Jurkat cells. NLuc signal were normalized to AUG-FF and compared between WT and DHX36 KO Jurkat cells. Data are represented as mean $\pm \mathrm{SD}, \mathrm{n}=9$. (C) In vitro translation using lysates derived from DHX36 WT and KO Jurkat cells for AUG-NLuc RNA and C9-RAN in GA frame RNA. NLuc signals were normalized to signal from DHX36 WT. Data are represented as mean $\pm S D, n=24$. Twotailed Student's t-test with Bonferroni and Welch's correction, ${ }^{*} P<0.05$; ${ }^{* * *} P<0.001$; ${ }^{* * *} P<0.0001$. 
Figure 4

A

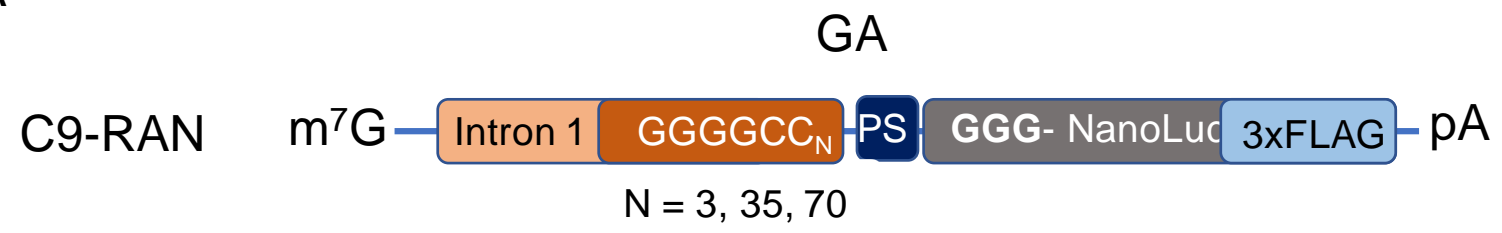

B

HeLa

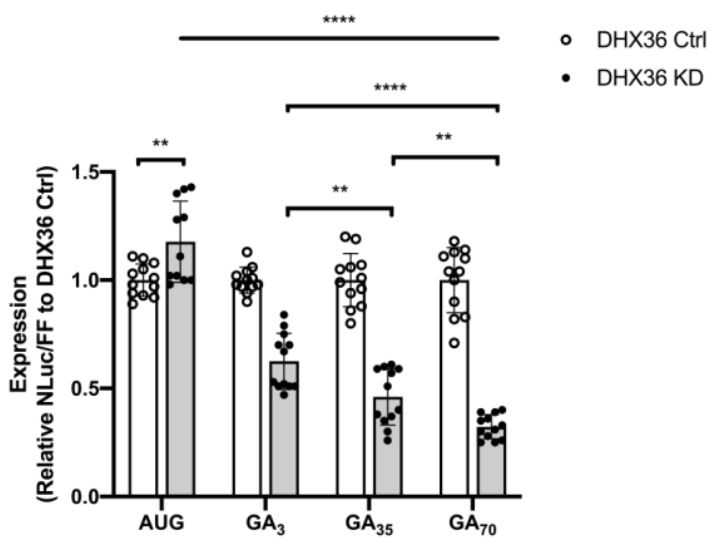

C Jurkat

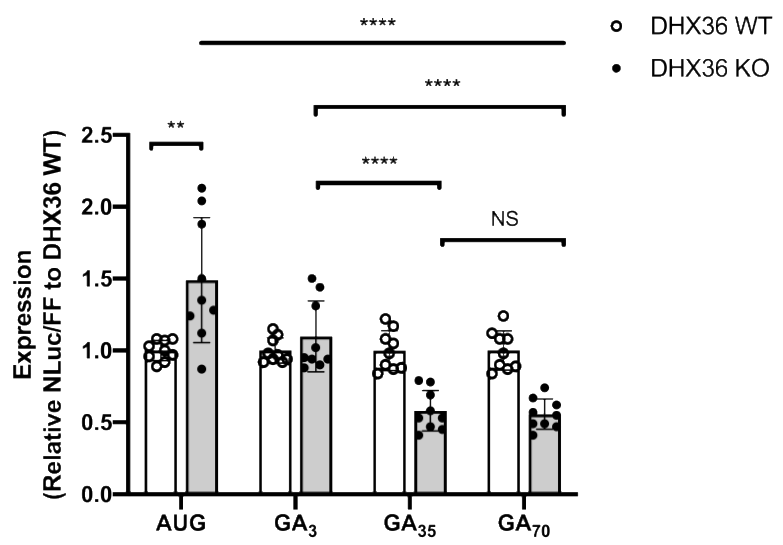

Figure 4: The effect of decreased DHX36 on C9RAN reporter expression is $\mathrm{G}_{4} \mathrm{C}_{2}$ repeat length dependent. (A) Schematic of previously published luciferase reporters of C9-RAN in GA frame harboring different repeat sizes. (B)-(C) Relative expression of AUG and C9-RAN translation from GA frames with 3, 35, and 70 repeats in Ctrl and DHX36 KD HeLa cells (B), and DHX36 WT and KO Jurkat cells. NLuc signal were normalized to AUG-FF. Data are represented as mean $\pm S D, n=9-12$. One-way ANOVA were performed to compare the statistical differences between repeat length in DHX36 $\mathrm{KD}$ or KO cell lines. Two-tailed Student's t-test with Bonferroni and Welch's correction were then perform to confirm the differences between multiple comparison, ${ }^{*} P<0.05$; ${ }^{* *} P<0.01 ;{ }^{* * *} P<0.0001$. 


\section{Figure 5}

A

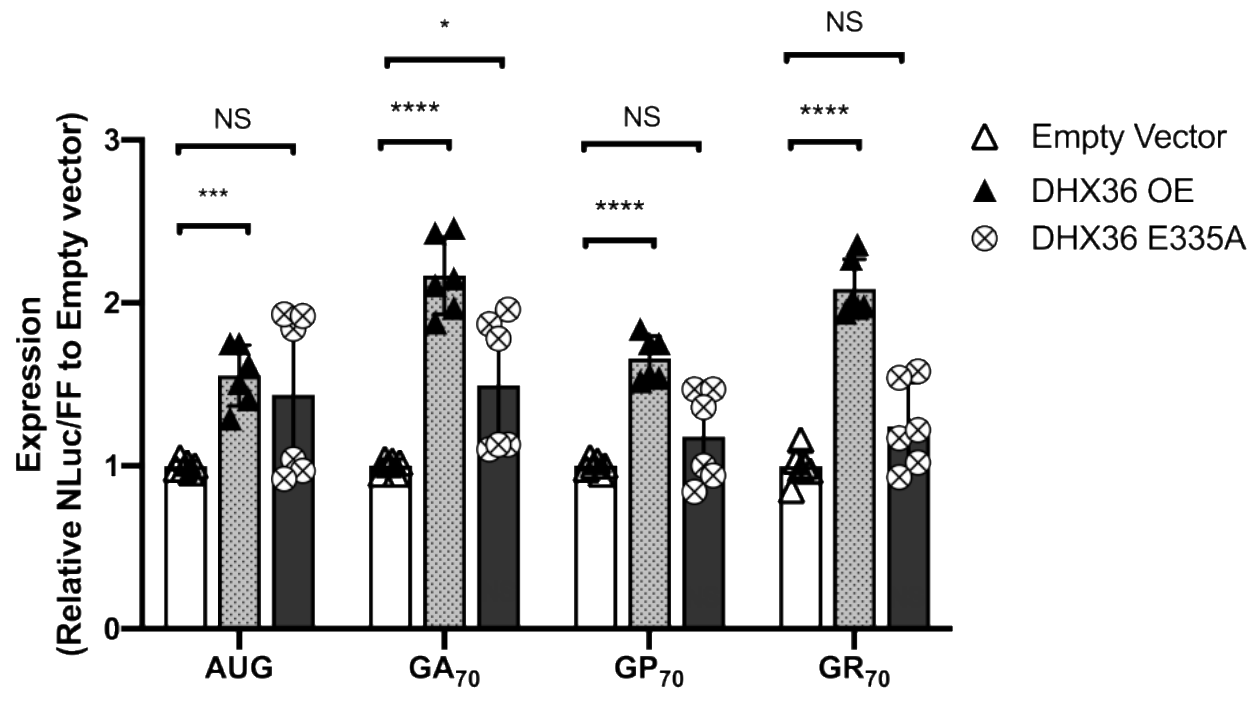

B

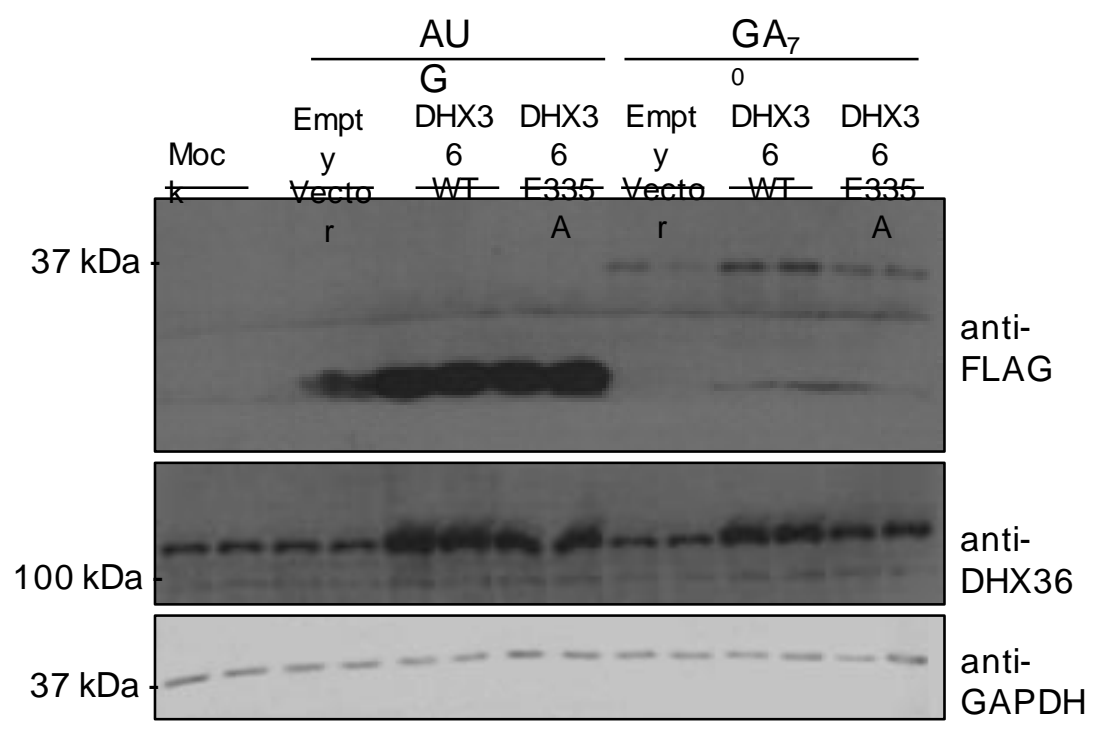

Figure 5: DHX36 overexpression enhances C9RAN reporter expression from $\mathrm{G}_{4} \mathrm{C}_{2}$ repeat RNA. (A) Relative expression of AUG and C9-RAN translation when cotransfecting reporter RNA and overexpression of empty vector, WT or E335A DHX36 
DNA plasmids in HeLa cells. Data are represented as mean $\pm S D, n=9$. Two-tailed Student's t-test with Bonferroni and Welch's correction, ${ }^{\star} P<0.05$; ${ }^{* \star \star} P<0.001$; ${ }^{* \star \star} P<$ 0.0001. (B) Western blots analysis of co-transfected AUG and C9-RAN luciferase reporters in RNA and empty vector, DHX36 WT or DHX36 E335A DNA plasmids in HeLa cells. GAPDH was blotted as internal control. 
Figure 6

A

$\mathrm{NLU}$

\section{FFLuc}

C
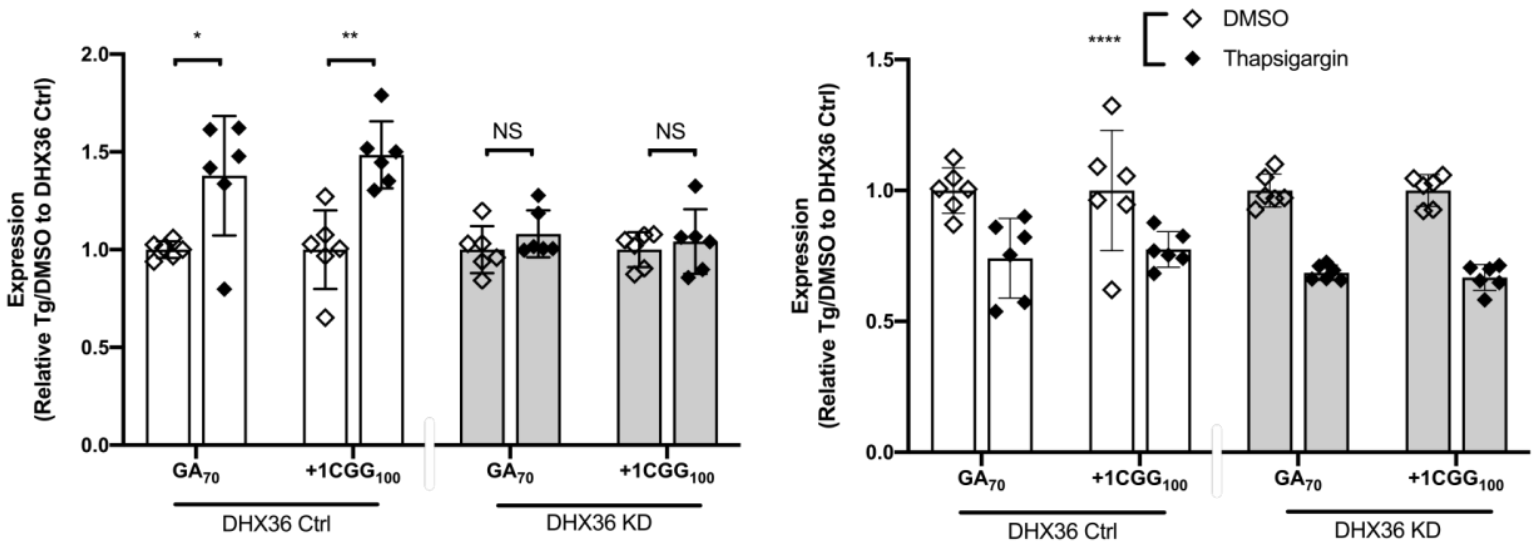

B

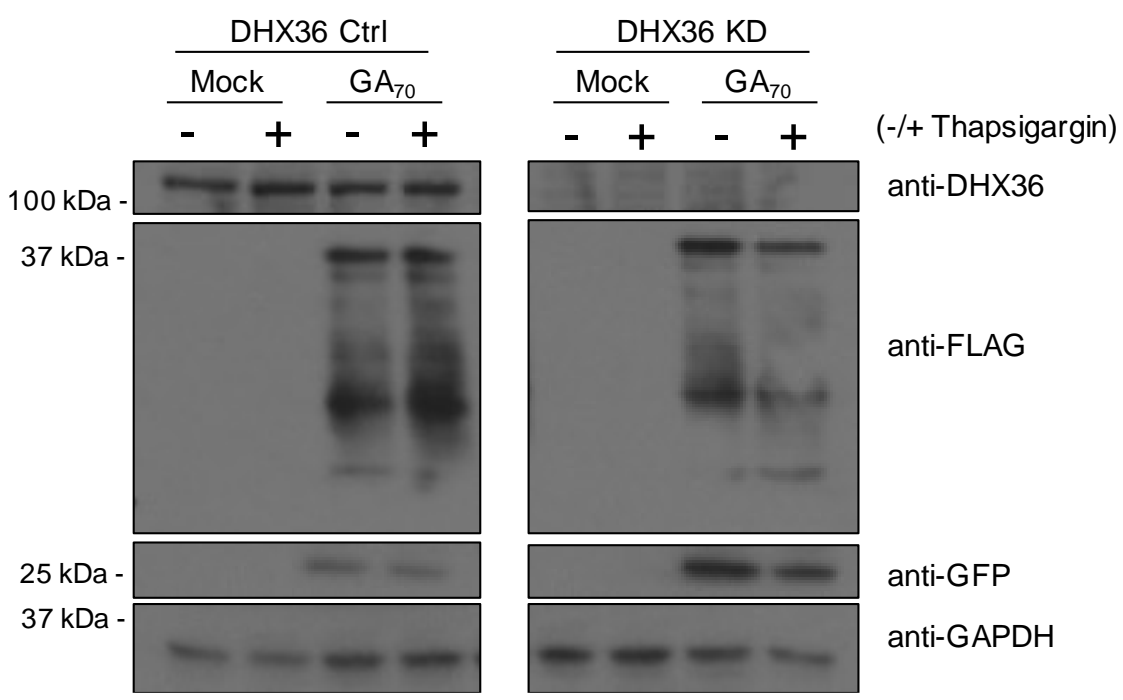

Figure 6: Knockdown of DHX36 prevents stress dependent upregulation of C9RAN reporter expression. (A) Relative expression of RAN translation in $\mathrm{G}_{4} \mathrm{C}_{2}$ and CGG repeat treated with $2 \mu \mathrm{M}$ thapsigargin or DMSO in Ctrl and DHX36 KD HeLa cells. NLuc (left) and FF (right) signal were represented as ratio of Thapsigargin treated cells to DMSO treated cells and compared between Ctrl and DHX36 KD HeLa cells. (B) Immunoblots of $\mathrm{G}_{4} \mathrm{C}_{2}$ and CGG RAN luciferase reporters in Ctrl and DHX36 KD HeLa cells treated with $2 \mu \mathrm{M}$ Thapsigargin. GFP was blotted as a transfection control and 
bioRxiv preprint doi: https://doi.org/10.1101/2021.04.25.441260; this version posted April 26, 2021. The copyright holder for this preprint (which

was not certified by peer review) is the author/funder, who has granted bioRxiv a license to display the preprint in perpetuity. It is made available under aCC-BY-NC-ND 4.0 International license.

GAPDH was blotted as internal control. For panel $A$, data are represented as mean $\pm S D, n=6$. two-way ANOVA was performed to discern effect of thapsigargin treatment across cell types. Two-tailed Student's t-test with Bonferroni and Welch's correction were performed to assess differences between individual groups. ${ }^{\star} P<0.05$; ${ }^{\star \star} P<0.01$; ${ }^{\star \star \star \star} P<0.0001$. 
Figure 7

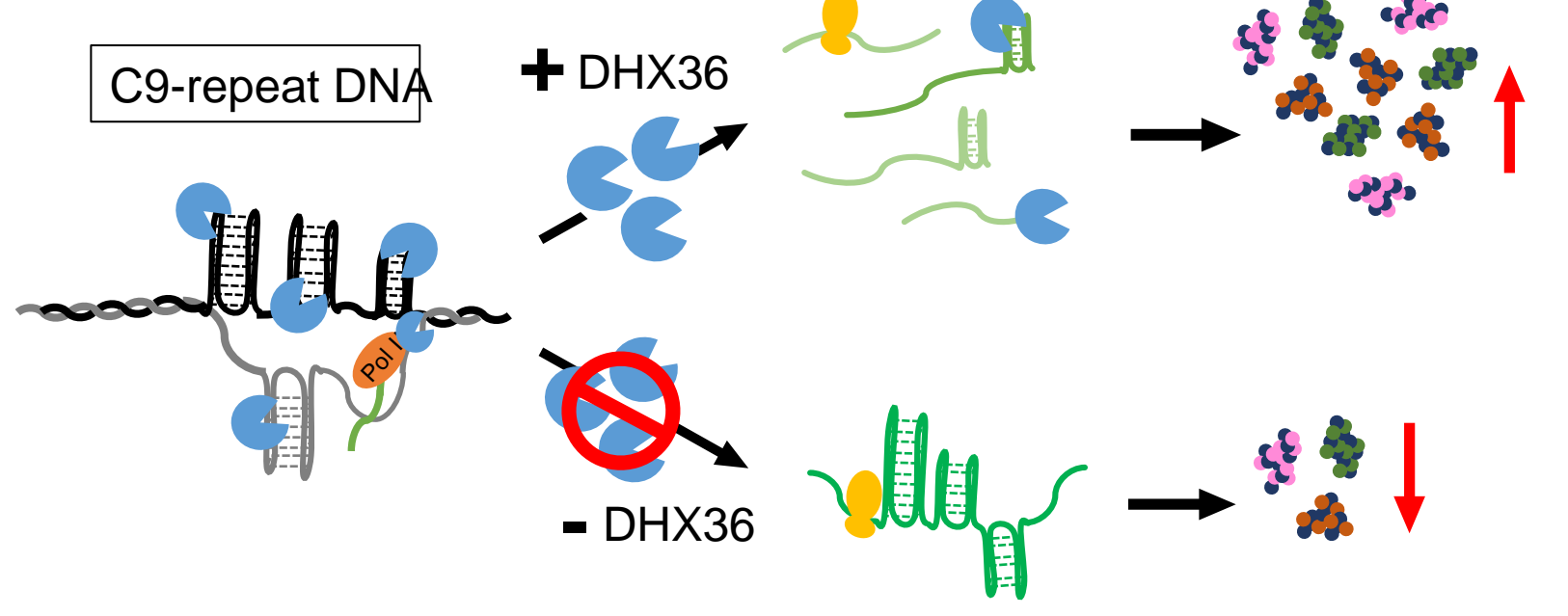

Figure 7: Model of DHX36 modulation of C9 RAN translation

DHX36 binds to G-quadruplex DNA and RNA structures. DHX36 aids transcription through large stretches of $\mathrm{G}_{4} \mathrm{C}_{2}$ repeat $\mathrm{RNA}$ in vitro but its effects in human cells with large repeats are unclear. Depletion of DHX36 decreases RAN translation from both CGG and C9-repeat reporters- both of which are capable of forming G-quadruplex structures- while increased DHX36 expression enhances C9RAN translation. These findings suggest a direct role for DHX36 in RAN translation of GC rich repeats. 


\section{Supplemental Figure 1}

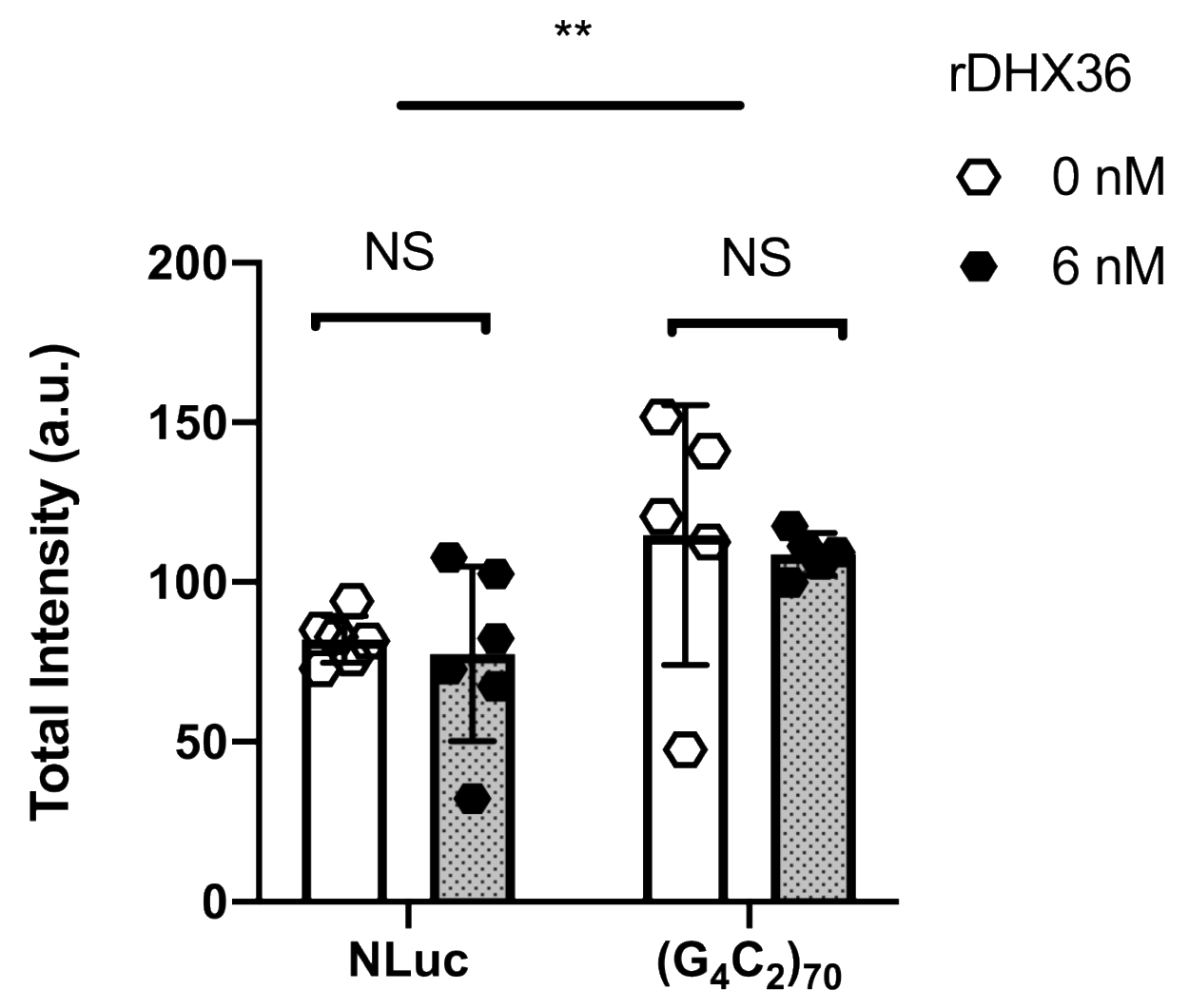

Supplemental Figure 1: Total RNA quantification of in vitro transcription. The total density of each lane were quantified after subtraction to the background signal. Data are presented as $\pm S D, n=5$ (NLuc) - $6\left(\mathrm{G}_{4} \mathrm{C}_{2}\right)_{70}$. Two-tailed pair t-test was performed to compared between with or without rDHX36, N.S. = not-significant. Two-way ANOVA was performed to compare differences between NLuc and $\left(\mathrm{G}_{4} \mathrm{C}_{2}\right)_{70}$ experimental groups, ${ }^{\star *} P<0.005$. 


\section{Supplemental Figure 2}

A

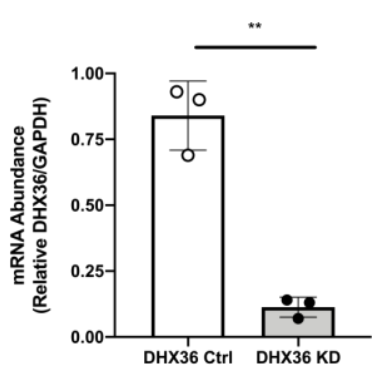

D

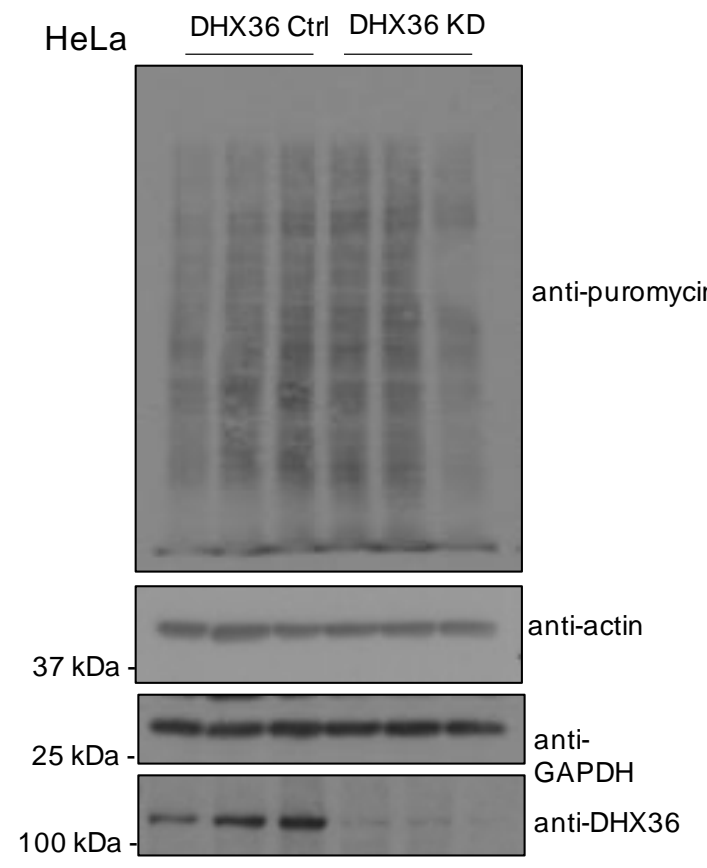

E

HeLa

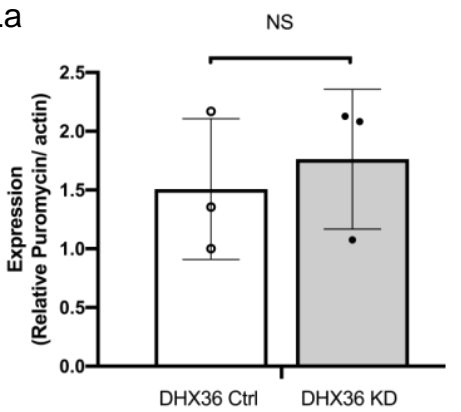

B

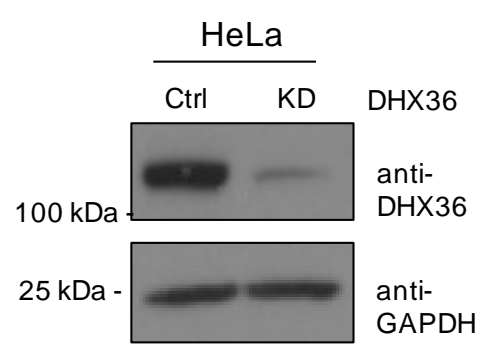

$\mathrm{F}$

HeLa

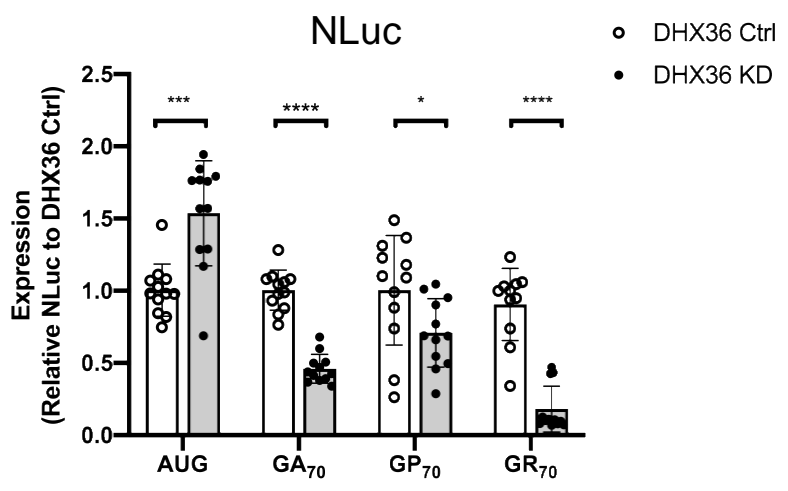

FFLuc

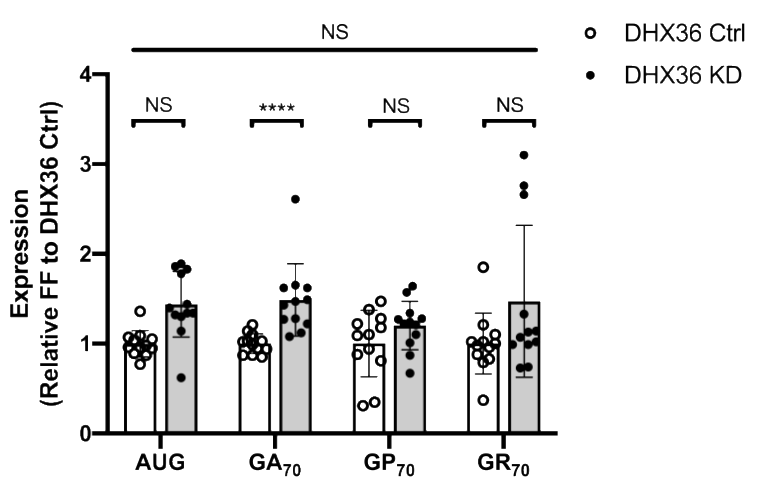


Supplemental Figure 2: Characterization of Control and DHX36 KD in HeLa cells. (A) Relative abundance of DHX36 mRNA in Ctrl and DHX36 KD HeLa cells as measured by qRT-PCR (normalized to GAPDH mRNA). Data are represented as mean $\pm S D, n=3$. Two-tailed Student's t-test with Bonferroni and Welch's correction, ${ }^{* *} P<0.01$ (B) Western blots of DHX36 in Ctrl and DHX36 KD HeLa cells. GAPDH was blotted as internal control. (C) Immuno-fluorescent images of Ctrl and DHX36 KD HeLa cells expressing DHX36, scale bar $=10 \mu \mathrm{m}$. (D\&E) Translation was monitored by puromycin incorporation and quantification was performed by normalizing puromycin to actin. Data are represented as mean $\pm S D, n=3$. (F) Relative NLuc or FF signal normalized to DHX36 WT. One-way ANOVA comparing FF signal between DHX36 control and KD groups in different treatment conditions. Then two-tailed Student's t-test with Bonferroni and Welch's correction was further performed to test for statistical difference between AUG and C9-RAN translation groups, N.S. = not-significant; ${ }^{*} P<0.05 ;{ }^{* \star \star} P<0.001$; ${ }^{\star * \star *} P<0.0001$. 


\section{Supplemental Figure 3}

A

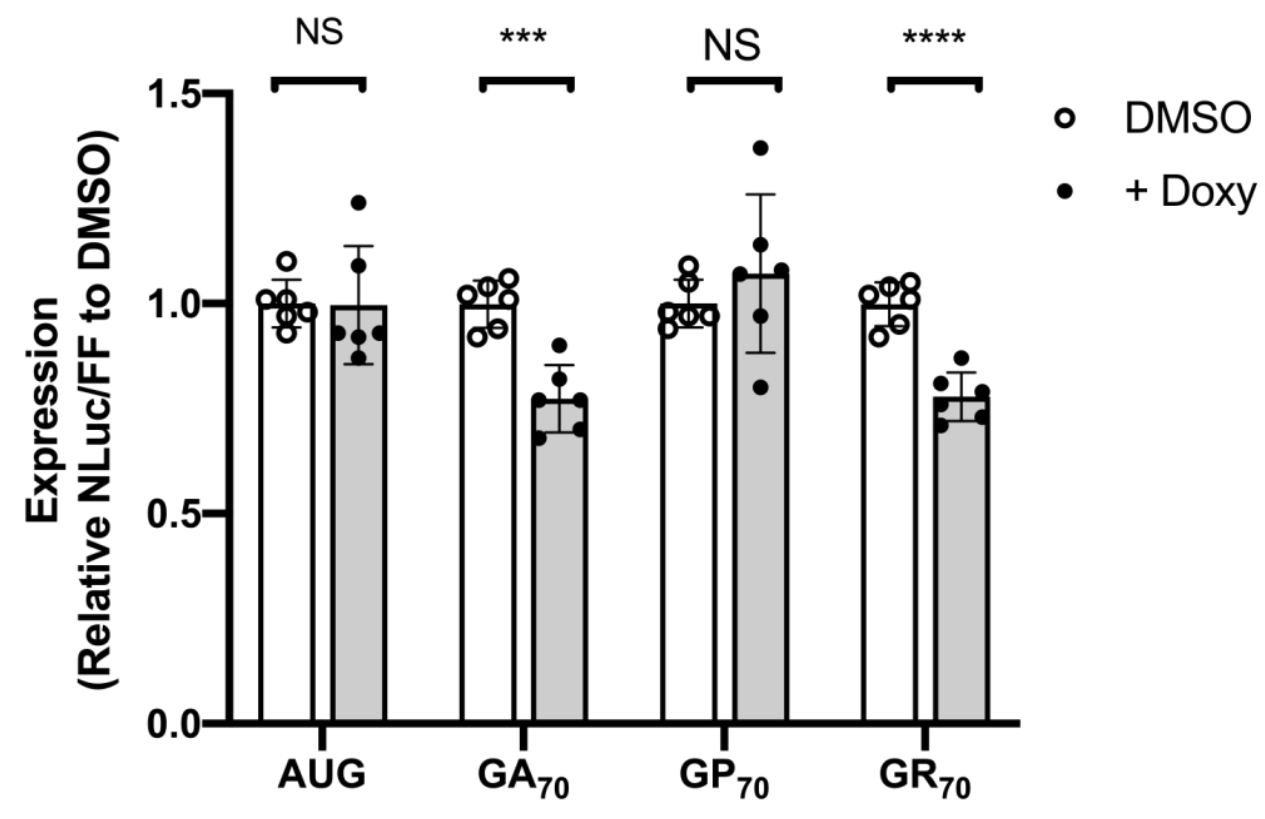

B

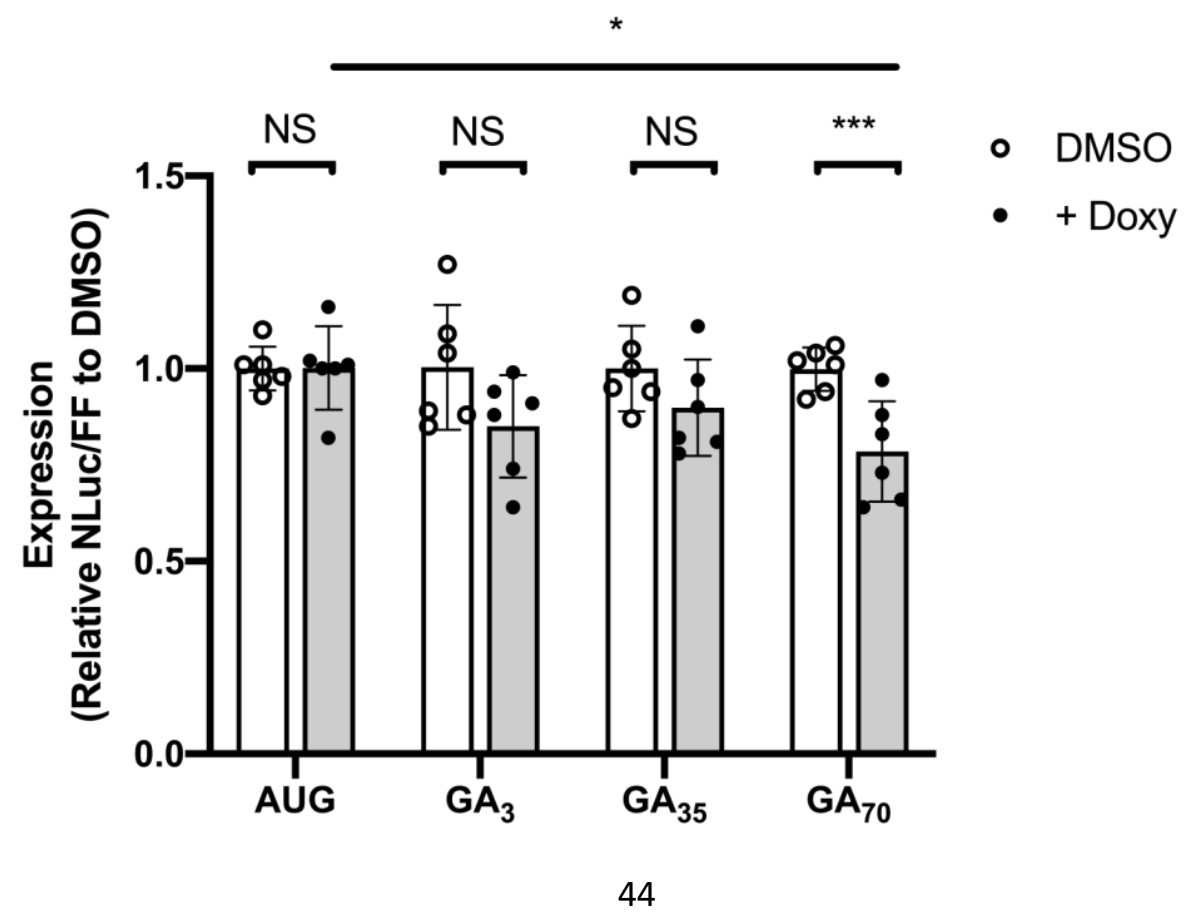


Supplemental Figure 3: C9RAN reporter expression in DHX36 KD inducible HeLa cells. treated with DMSO or Doxycycline. Inducible DHX36 KD HeLa cells were treated with DMSO or Doxy prior plasmids transfection. (A) Relative expression of AUG and C9-RAN translation in GA (+0), GP $(+1)$, and GR (+2) frames with 70 repeats. (B) Relative expression of AUG and C9-RAN translation from GA frames with 3, 35, and 70 repeats. NLuc signal were normalized to AUG-FF translation. Data are represented as mean $\pm S D, n=6$. One-way ANOVA was performed to compare the statistical differences between repeat length in treatment of Doxycycline. Two-tailed Student's t-test with Bonferroni and Welch's correction, ${ }^{*} P<0.05$; ${ }^{* * \star} P<0.001 ;{ }^{* * \star *} P<0.0001$. 


\section{Supplemental Figure 4}

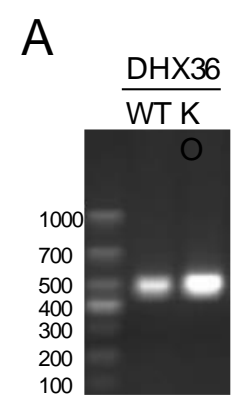

B
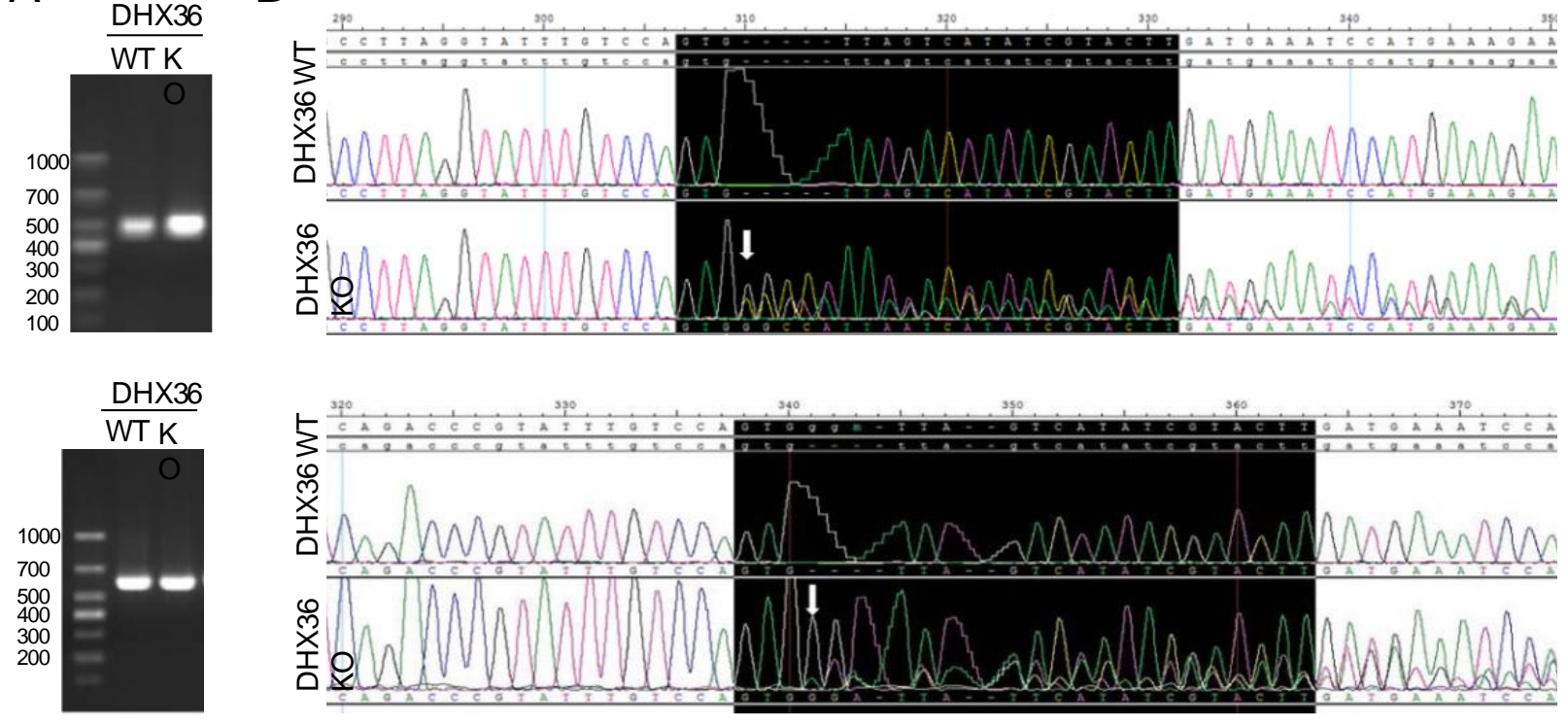

C

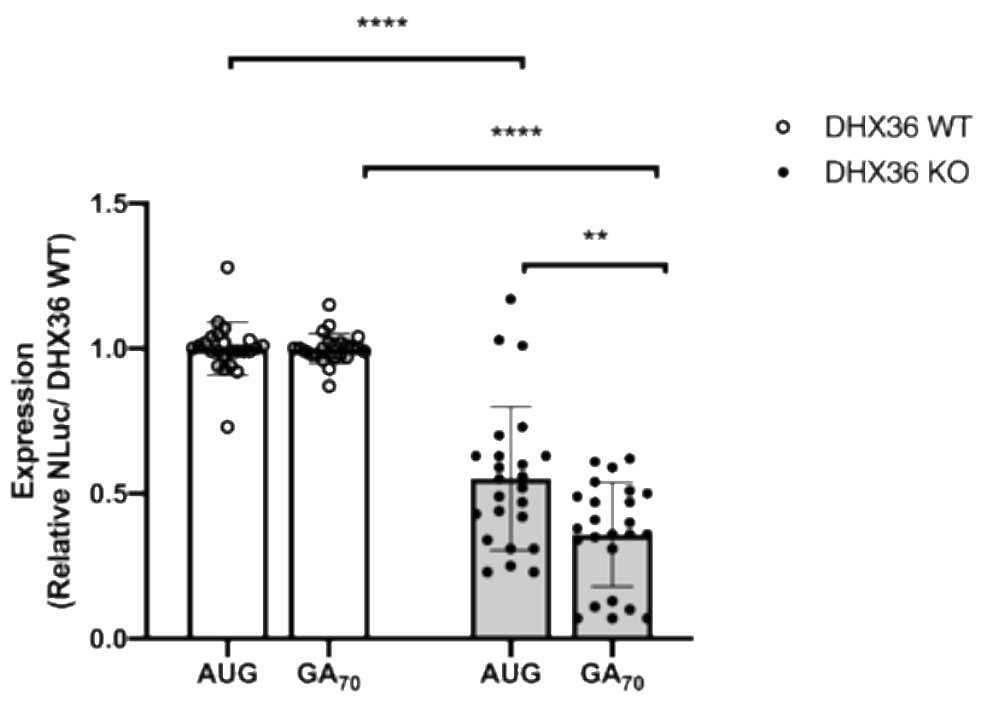

Supplemental Figure 4: Generation of DHX36 Knockout Jurkat cell lines. (A) PCR (top) and RT-PCR products (bottom) from primers flanking the DHX36 gRNA site (B) Alignment of Sanger sequencing data from PCR (top) and RT-PCR (bottom) products. gRNA targeting site was shaded in black. Arrow indicates the site of INDEL mutation. 
The DHX36 WT clone was identified and confirmed as a negative KO clone with genotype of the target gene identical to the parental cell line (INDEL:0/0). The DHX36 $\mathrm{KO}$ clone was identified and confirmed with a $5 \mathrm{bp}$ insertion on one allele and $6 \mathrm{bp}$ insertion on the other allele at the targeted site (INDEL: $+5 /+6)$. (C) In vitro translation assay demonstrates knockout of DHX36 preferentially decreases C9-RAN translation compared to AUG-NLUC control. NLuc signal were normalized to DHX36 WT. Data are represented as mean $\pm S D, n=24$. Two-tailed Student's t-test with Bonferroni and Welch's correction, ${ }^{\star \star} P<0.01 ;{ }^{* \star \star *} P<0.0001$. 


\section{Supplemental Figure 5}

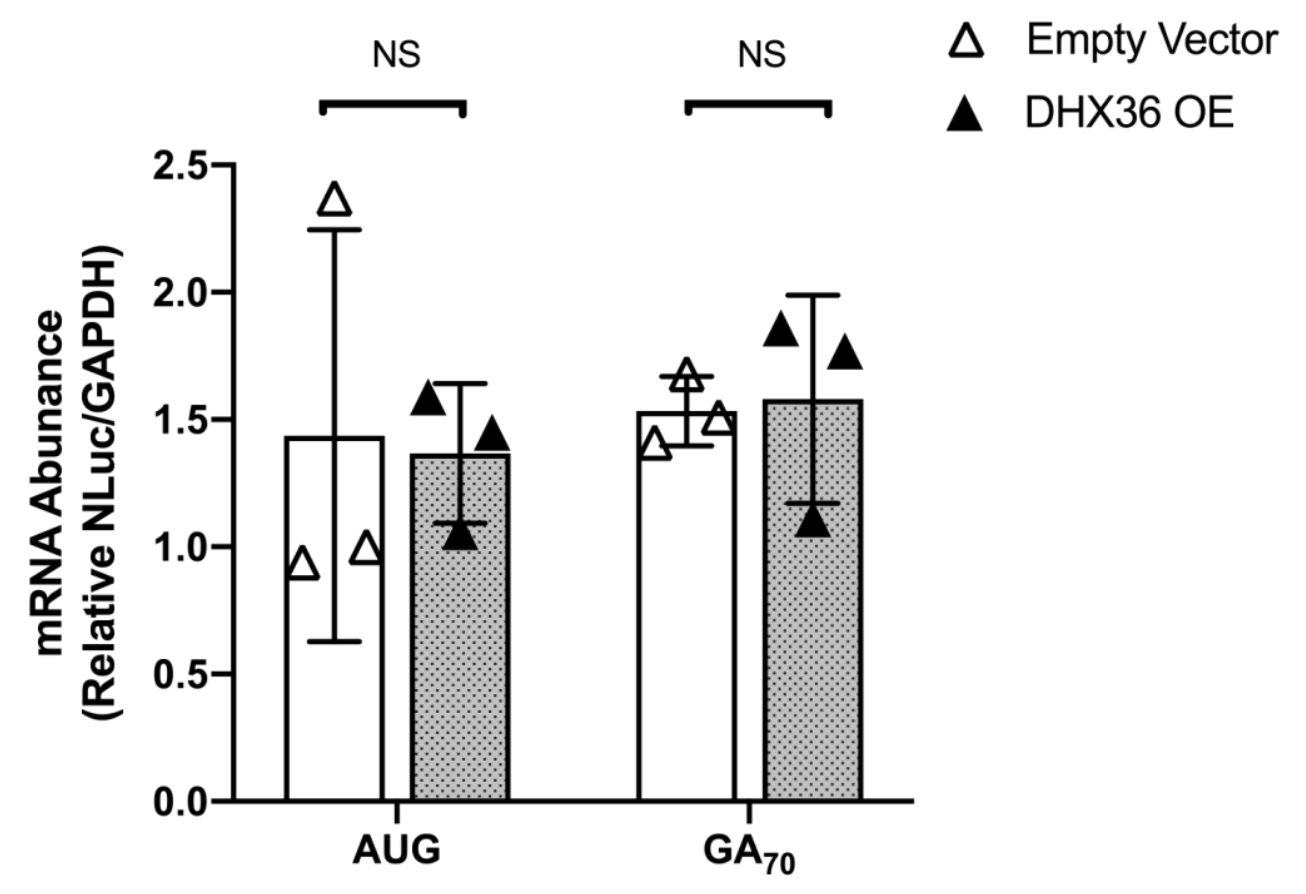

Supplemental Figure 5: DHX36 overexpression effect on C9RAN mRNA abundance from transfected plasmids. Relative expression of AUG and C9-RAN translation when co-transfecting reporter DNA and overexpression of empty vector, DHX36 WT or DHX36 E335A DNA plasmids in HeLa cells. Data are represented as mean $\pm \mathrm{SD}, \mathrm{n}=9$. Two-tailed Student's t-test with Bonferroni and Welch's correction, ${ }^{*} P<$ $0.05 ;{ }^{* *} P<0.01 ;{ }^{* \star *} P<0.001$. (B) qRT-PCR detecting NLuc mRNA from cells transfected with empty vector or DHX36 overexpression in HeLa cells. Data are represented as mean $\pm S D, n=3$. Two-tailed Student's t-test with Bonferroni and Welch's correction, not significant. 


\section{Supplemental Figure 6}

A

HeLa

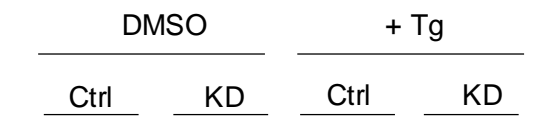

$\mathrm{DHX} 36$

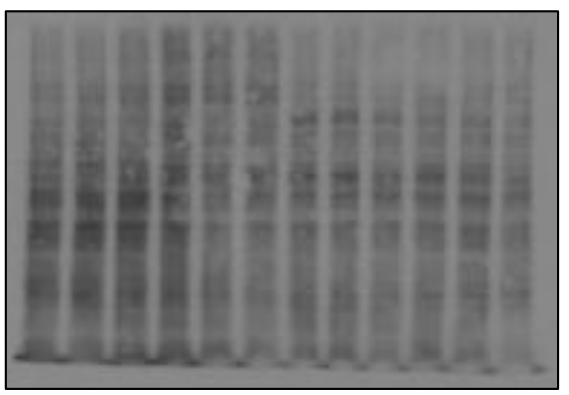

anti-puromycin
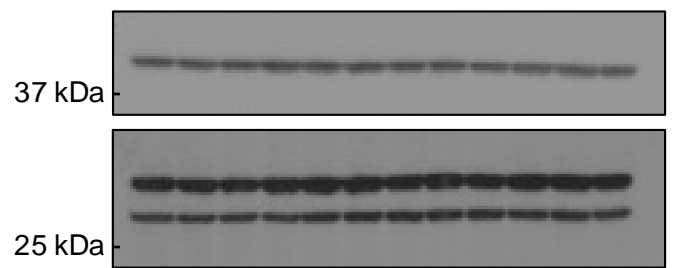

$100 \mathrm{kDa}$

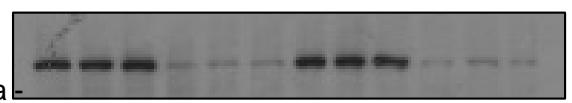

B

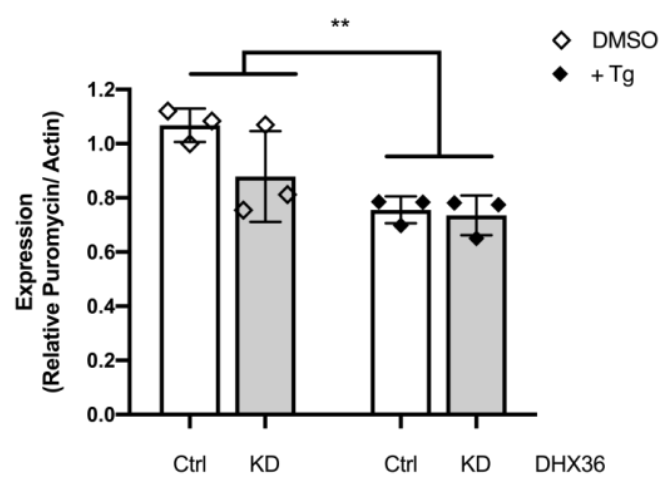

Supplemental Figure 6: Global protein translation in DHX36 KD HeLa cells under Thapsigargin stress. (A-B) Effect on protein synthesis under Tg stress was monitored by puromycin incorporation and quantification was performed by normalizing puromycin to actin. With treatment of $\mathrm{Tg}$, there is a decrease on global translation. Data are represented as mean $\pm S D, n=3$. One-way ANOVA compared between DMSO and $\mathrm{Tg}$ treated groups, ${ }^{* *} P<0.01$. 
Figure 1

D

\section{AUG-NLUC plasmid}

$\operatorname{rDHX36}(6 \mathrm{nM})-+-++-++-+$

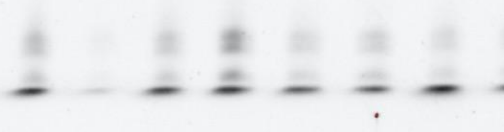


bioRxiv preprint doi: https://doi.org/10.1101/2021.04.25.441260; this version posted April 26, 2021. The copyright holder for this preprint (which was not certified by peer review) is the author/funder, who has granted bioRxiv a license to display the preprint in perpetuity. It is made available under aCC-BY-NC-ND 4.0 International license.

\section{Figure 1}

D

\section{GA70 plasmid}

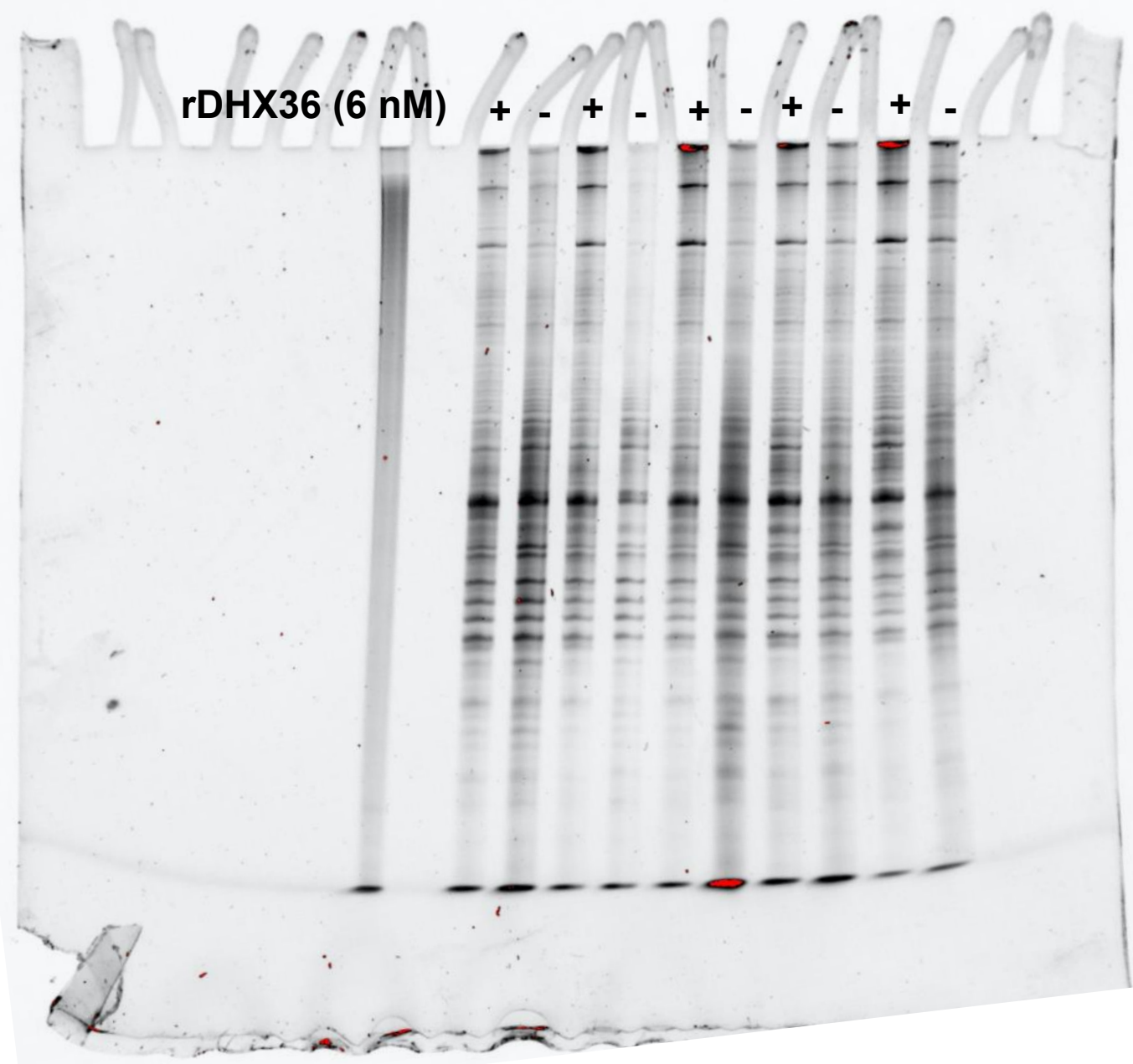


bioRxiv preprint doi: https://doi.org/10.1101/2021.04.25.441260; this version posted April 26, 2021. The copyright holder for this preprint (which was not certified by peer review) is the author/funder, who has granted bioRxiv a license to display the preprint in perpetuity. It is made available under aCC-BY-NC-ND 4.0 International license.

\section{Figure 2}

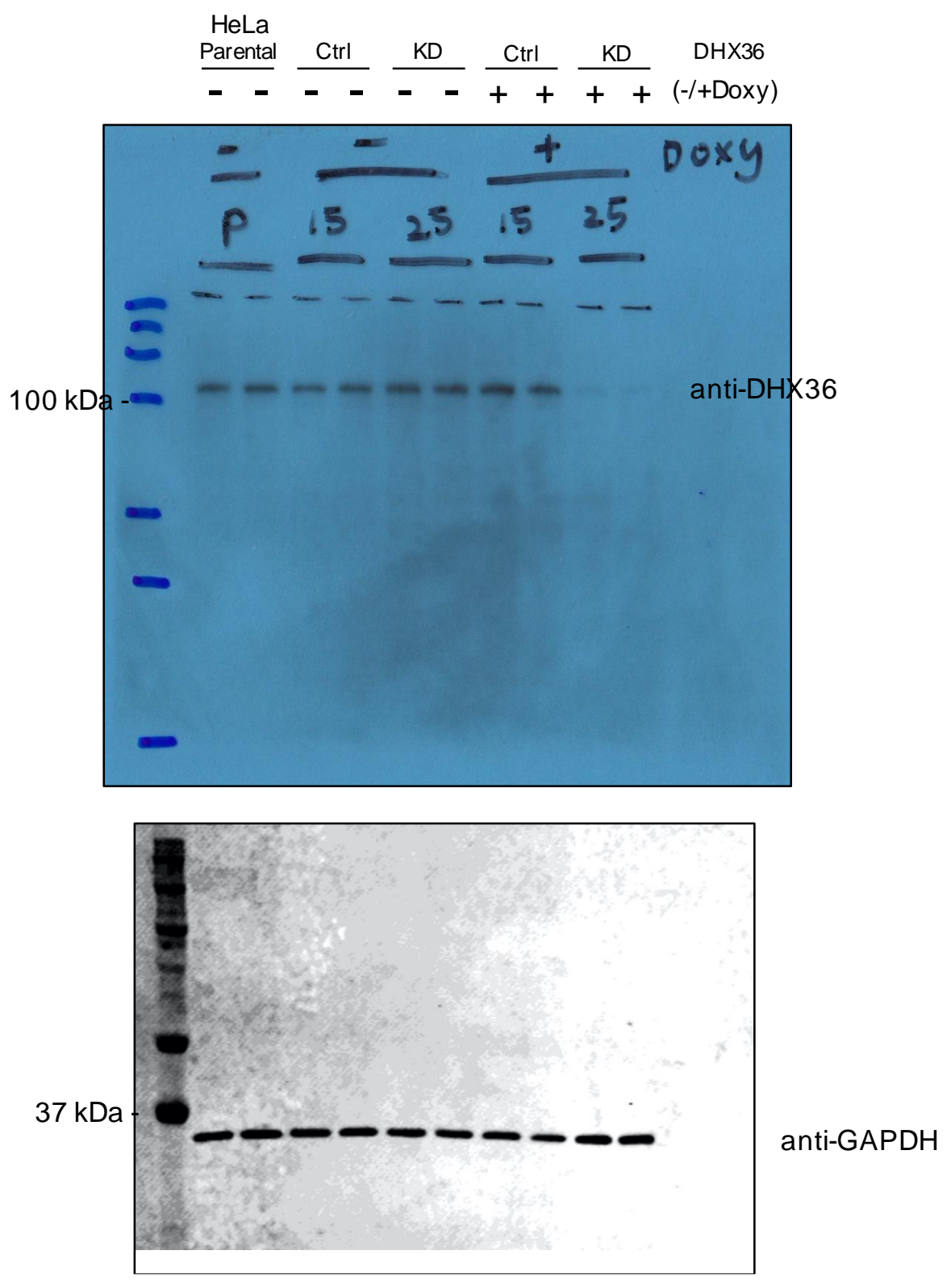


bioRxiv preprint doi: https://doi.org/10.1101/2021.04.25.441260; this version posted April 26, 2021. The copyright holder for this preprint (which was not certified by peer review) is the author/funder, who has granted bioRxiv a license to display the preprint in perpetuity. It is made available under aCC-BY-NC-ND 4.0 International license.

\section{Figure 2}

$E$
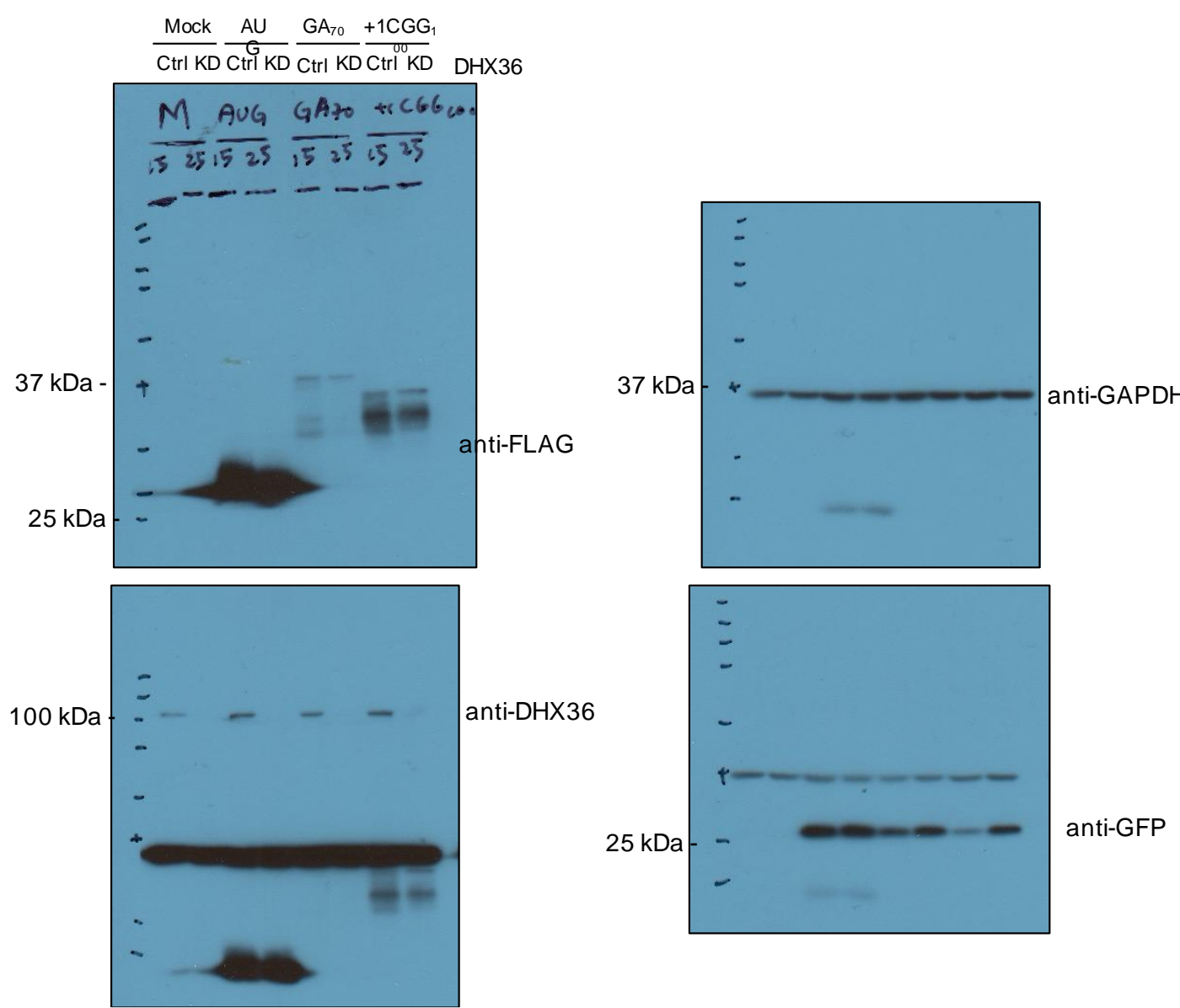
bioRxiv preprint doi: https://doi.org/10.1101/2021.04.25.441260; this version posted April 26, 2021. The copyright holder for this preprint (which was not certified by peer review) is the author/funder, who has granted bioRxiv a license to display the preprint in perpetuity. It is made available under aCC-BY-NC-ND 4.0 International license.

Figure 3

A
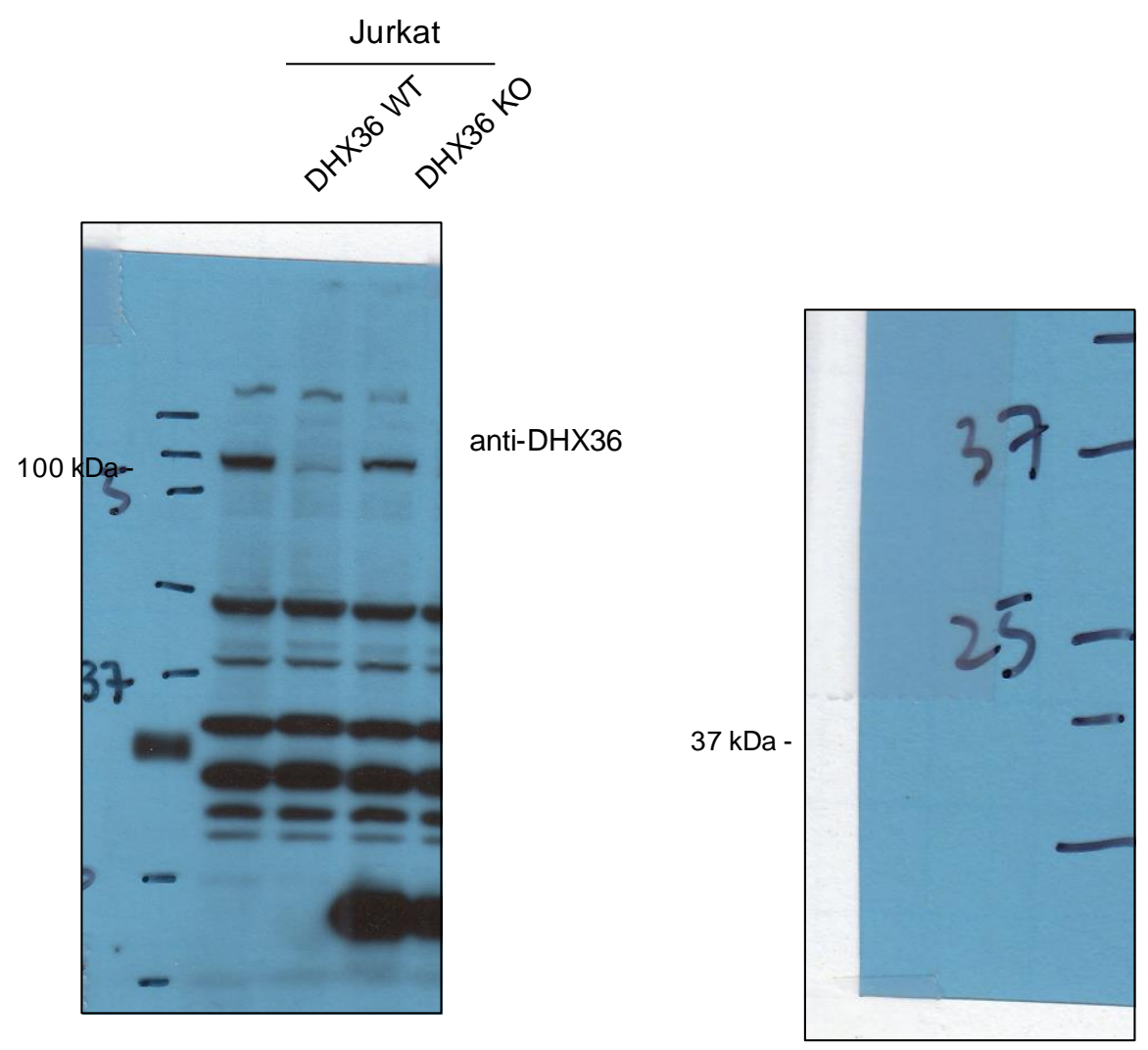

anti-actin 
bioRxiv preprint doi: https://doi.org/10.1101/2021.04.25.441260; this version posted April 26, 2021. The copyright holder for this preprint (which was not certified by peer review) is the author/funder, who has granted bioRxiv a license to display the preprint in perpetuity. It is made available under aCC-BY-NC-ND 4.0 International license.

\section{Figure 5 B}
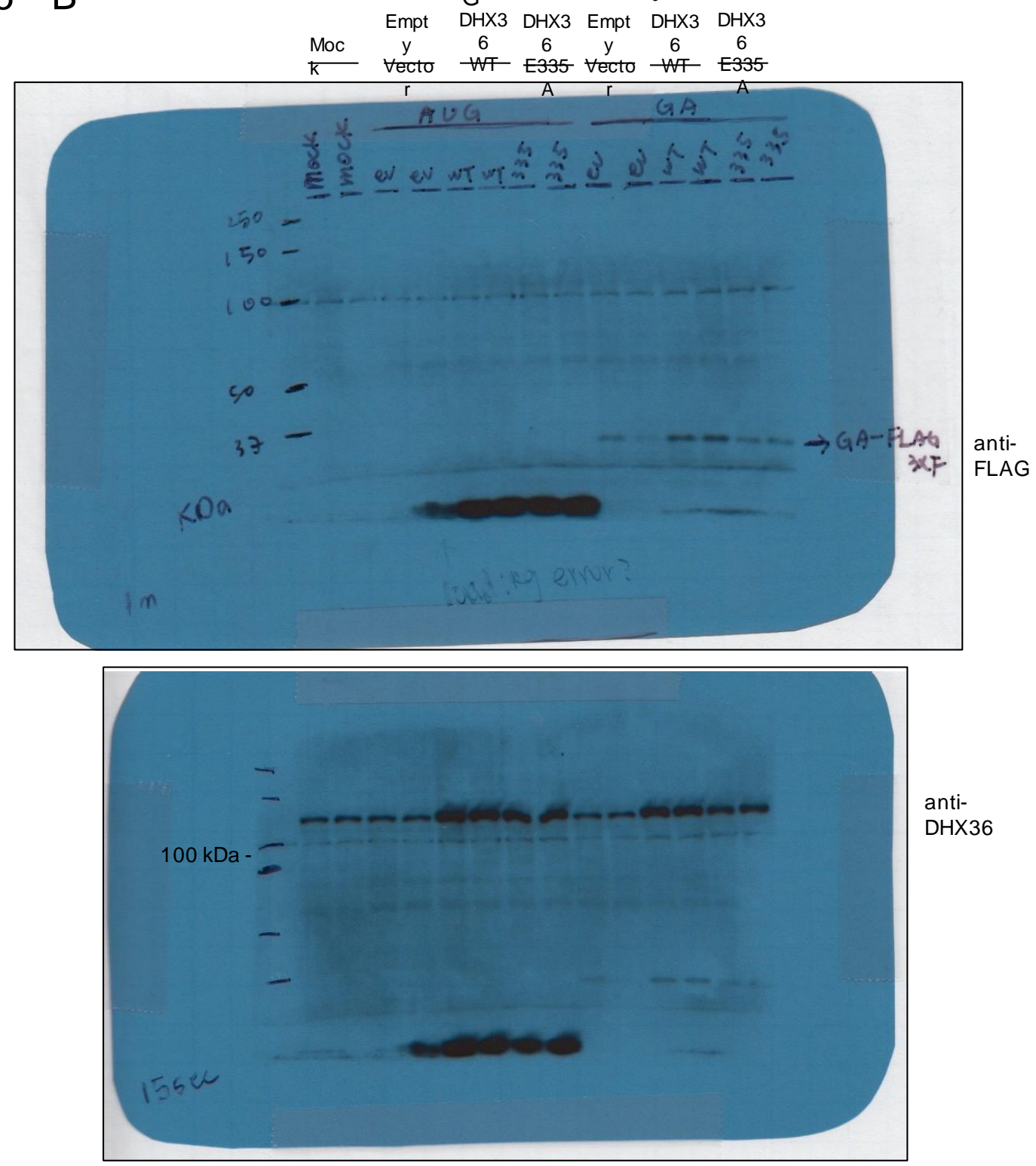

anti-

DHX36

$37 \mathrm{kDa}$

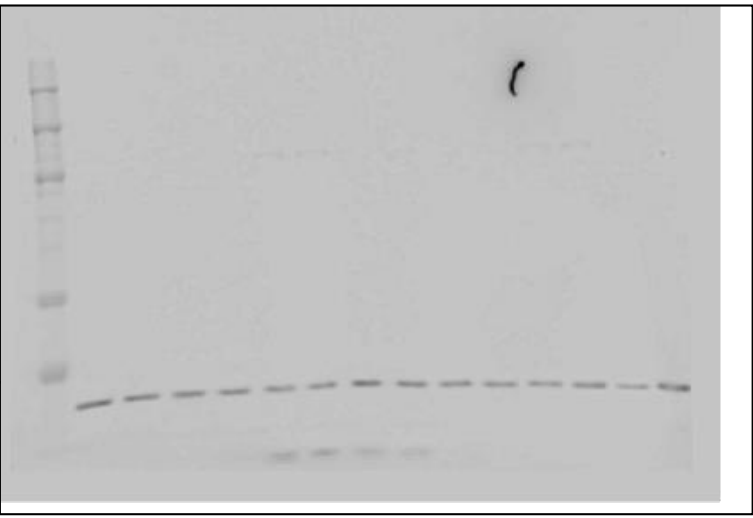

anti-

GAPDH 
bioRxiv preprint doi: https://doi.org/10.1101/2021.04.25.441260; this version posted April 26, 2021. The copyright holder for this preprint (which was not certified by peer review) is the author/funder, who has granted bioRxiv a license to display the preprint in perpetuity. It is made available under aCC-BY-NC-ND 4.0 International license.

Figure $6 \mathrm{~B}$

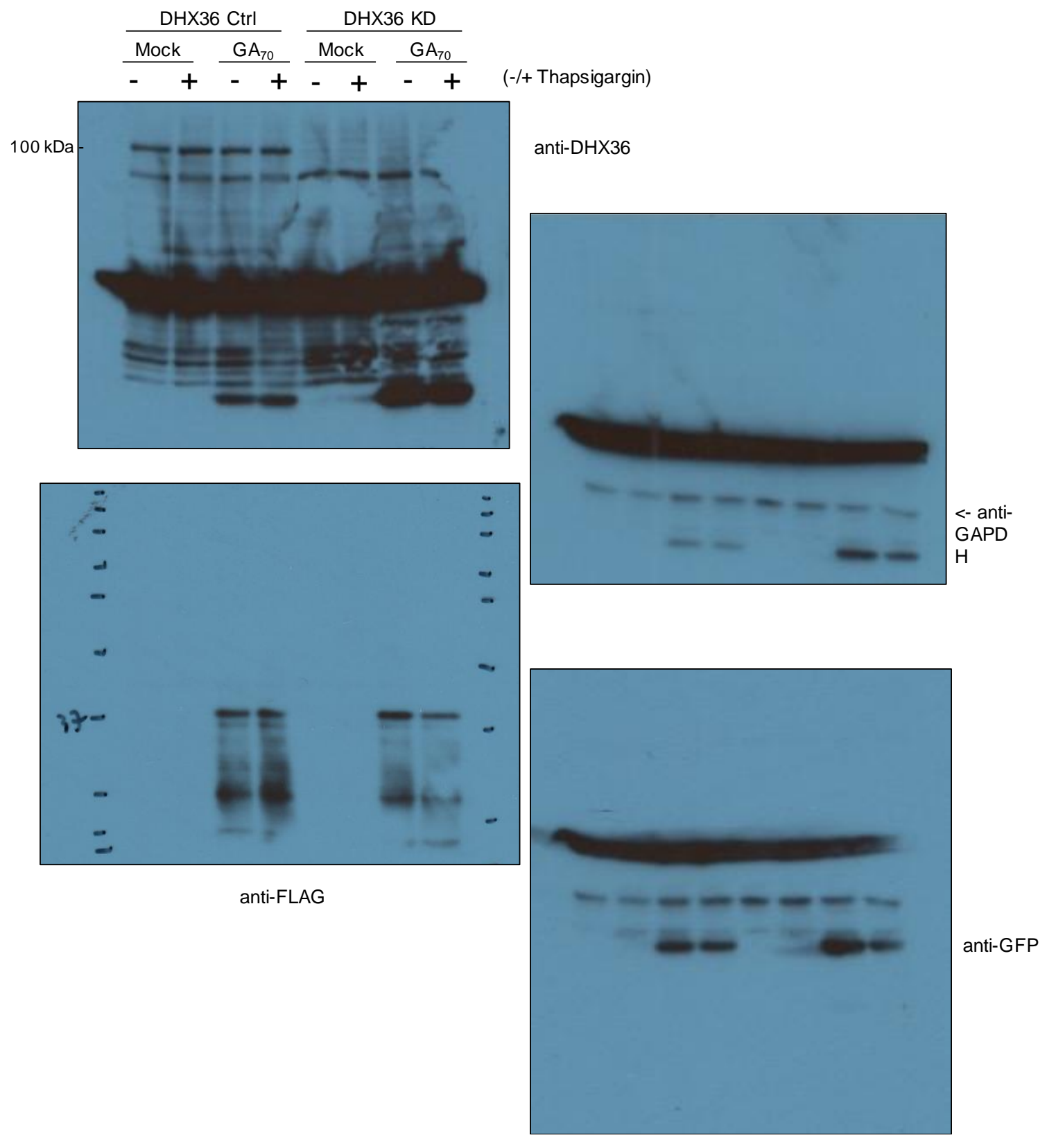




\section{Supplemental Figure 1}

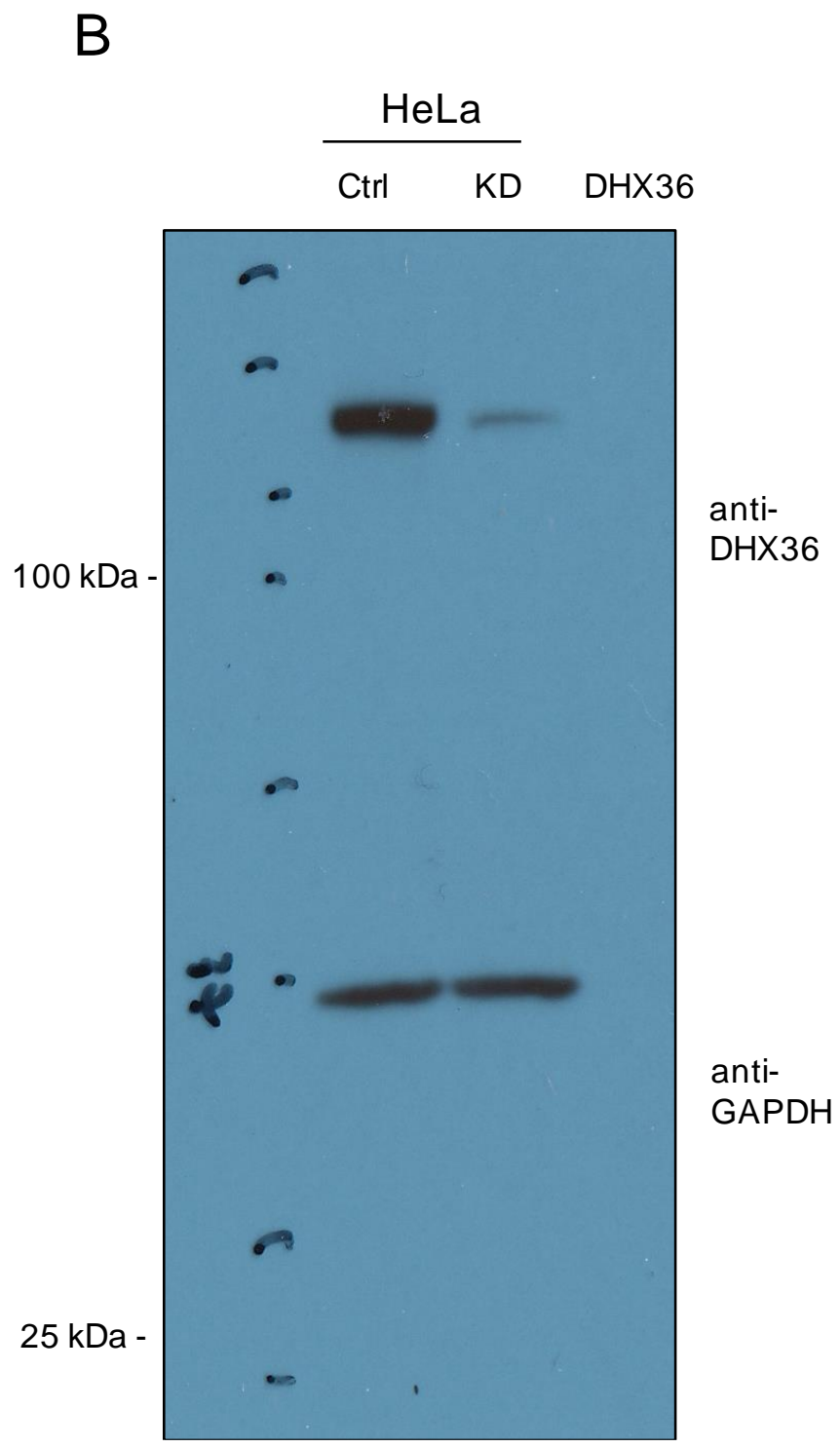


bioRxiv preprint doi: https://doi.org/10.1101/2021.04.25.441260; this version posted April 26, 2021. The copyright holder for this preprint (which

was not certified by peer review) is the author/funder, who has granted bioRxiv a license to display the preprint in perpetuity. It is made available under aCC-BY-NC-ND 4.0 International license.

\section{Supplemental Figure 1}
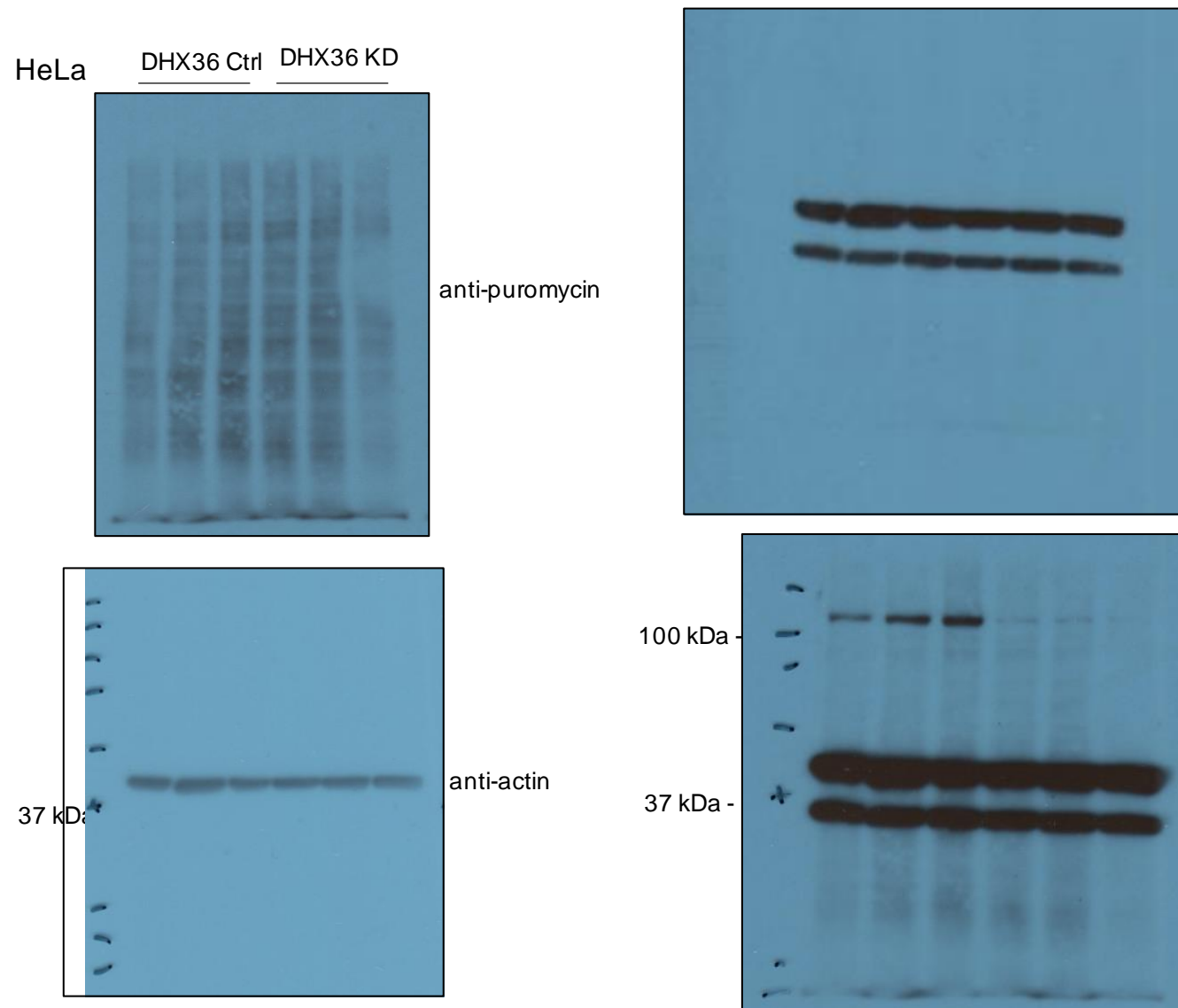

anti-actin

anti-

GAPDH

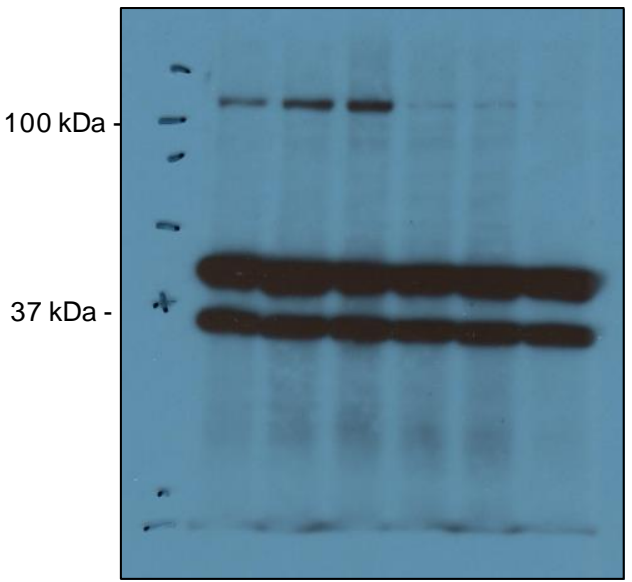

anti-DHX36

anti-

GAPDH 
bioRxiv preprint doi: https://doi.org/10.1101/2021.04.25.441260; this version posted April 26, 2021. The copyright holder for this preprint (which was not certified by peer review) is the author/funder, who has granted bioRxiv a license to display the preprint in perpetuity. It is made available under aCC-BY-NC-ND 4.0 International license.

\section{Supplemental Figure 5}

A

HeLa $\frac{\mathrm{DMSO}}{\mathrm{Ctrl} \quad \mathrm{KD}} \stackrel{+\mathrm{Tg}}{\mathrm{Ctrl} \quad \mathrm{KD}}$ DHX36

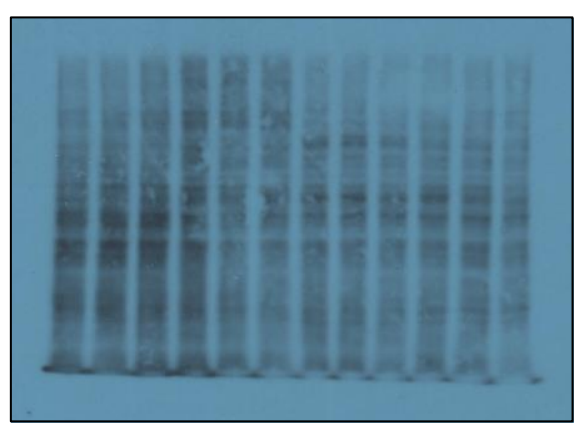

anti-puromycin
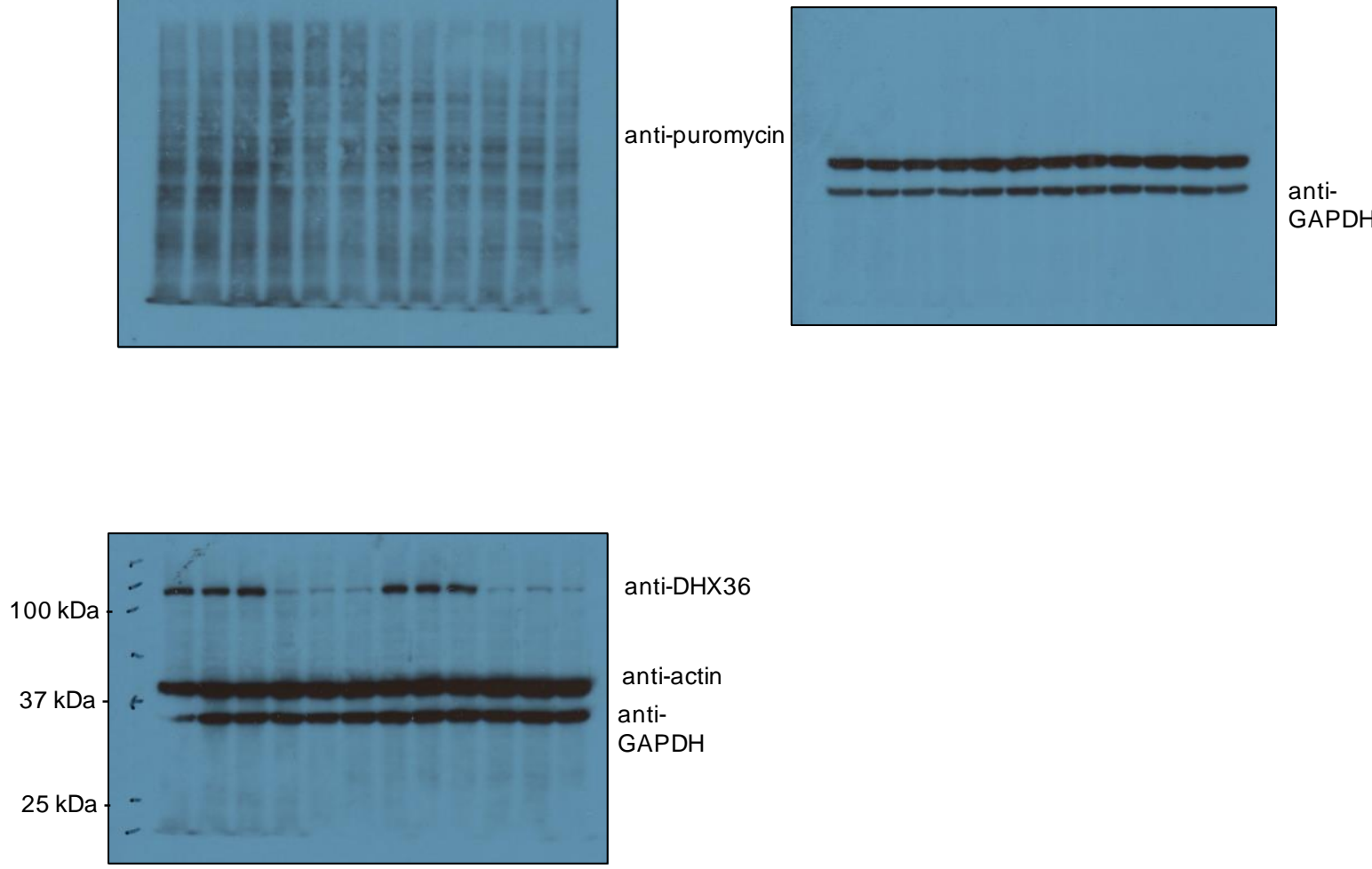

anti-DHX36

anti-actin

anti-

GAPDH

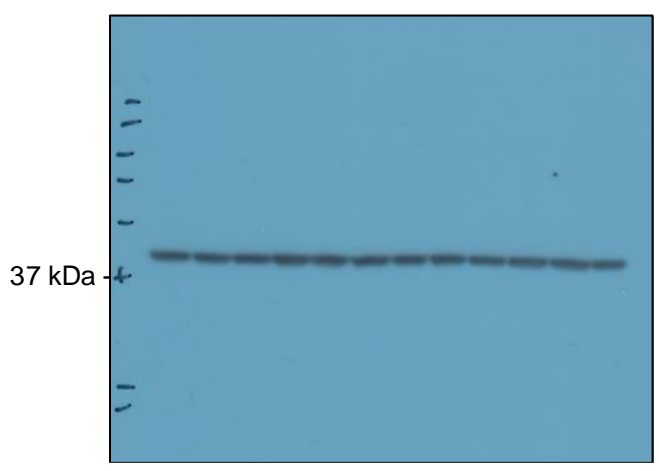

anti-actin 